\title{
Evaluation of Synroc-C as a Second-Generation Waste Form
}

\author{
J. W. Shade
}

August 1986

Prepared for the U.S. Department of Energy under Contract DE-AC06-76RLO 1830

Pacific Northwest Laboratory

Operated for the U.S. Department of Energy by Battelle Memorial Institute 


\title{
DISCLAIMER
}

This report was prepared as an account of work sponsored by an agency of the United States Government. Neither the United States Government nor any agency thereof, nor any of their employees, makes any warranty, express or implied, or assumes any legal liability or responsibility for the accuracy, completeness, or usefulness of any information, apparatus, product, or process disclosed, or represents that its use would not infringe privately owned rights. Reference herein to any specific commercial product, process, or service by trade name, trademark, manufacturer, or otherwise, does not necessarily constitute or imply its endorsement, recommendation, or favoring by the United States Government or any agency thereof. The views and opinions of authors expressed herein do not necessarily state or reflect those of the United States Government or any agency thereof.

\author{
PACIFIC NORTHWEST LABORATORY \\ operated by \\ BATTELLE \\ for the \\ UNITED STATES DEPARTMENT OF ENERGY \\ under Contract DE-AC06-76RLO 1830
}

\begin{tabular}{|c|c|}
\hline \multirow{2}{*}{\multicolumn{2}{|c|}{ Printed in the United States of America }} \\
\hline & \\
\hline \multicolumn{2}{|c|}{ Available from } \\
\hline \multicolumn{2}{|c|}{ United States Department of Commerce } \\
\hline \multicolumn{2}{|c|}{$\begin{array}{c}5285 \text { Port Royal Road } \\
\text { Springfield, Virginia } 22161\end{array}$} \\
\hline \multirow{2}{*}{\multicolumn{2}{|c|}{$\begin{array}{l}\text { NTIS Price Codes } \\
\text { Microfiche A01 }\end{array}$}} \\
\hline & \\
\hline \multicolumn{2}{|c|}{ Printed Copy } \\
\hline Pages & $\begin{array}{l}\text { Price } \\
\text { Codes }\end{array}$ \\
\hline $001-025$ & $\mathrm{~A} 02$ \\
\hline $026-050$ & $\mathrm{~A} 03$ \\
\hline $051-075$ & $\mathrm{~A} 04$ \\
\hline $076-100$ & $\mathrm{~A} 05$ \\
\hline $101-125$ & $A 06$ \\
\hline $126-150$ & $\mathrm{~A} 07$ \\
\hline $151-175$ & $\mathrm{~A} 08$ \\
\hline $176-200$ & $A 09$ \\
\hline $201-225$ & A010 \\
\hline $226-250$ & A011 \\
\hline $251-275$ & A012 \\
\hline $276-300$ & $\mathrm{~A} 013$ \\
\hline
\end{tabular}


EVALUATION OF SYNROC-C AS A SECOND-GENERATION WASTE FORM

J. W. Shade

August 1986

Prepared for the U.S. Department of Energy under Contract DE-AC06-76RLO 1830

Pacific Northwest Laboratory Richland, Washington 99352 



\section{ABSTRACT}

The durability of a crystalline titanate waste form, Synroc-C, was evaluated as a second-generation waste form by leach testing. Tests using both monolith and high surface area powdered samples were used with silicate water and brines at $90^{\circ} \mathrm{C}$ and $150^{\circ} \mathrm{C}$ for up to 90 days. In addition, low surface areato-volume ratio, 1-day leach tests were conducted between $90^{\circ} \mathrm{C}$ and $250^{\circ} \mathrm{C}$ to determine forward-direction leach rates and activation energies. Dissolution rates of $\mathrm{Cs}, \mathrm{Mo}, \mathrm{Ba}$, and $\mathrm{U}$ indicated that Synroc-C generally performed about an order of magnitude better than uranium-doped 76-68 glass. The release of Cs and Mo from Synroc-C, at least initially, may be primarily from intergranular regions of the material. The activation energy for the release of these elements from glass was about $9 \mathrm{kcal} / \mathrm{mol}$ but less than $3 \mathrm{kcal} / \mathrm{mol}$ for Synroc-c. In long-term tests, uranium dissolution may be controlled more by the formation of uranium alteration products than by release from the waste form. 
SUMMARY

Both glass and crystaliine ceramic materials are being considered as waste containment forms for nuclear fuel reprocessing wastes and are under consideration along with unreprocessed spent fuel for disposal in geologic repositories. Although borosilicate glasses have received the most development effort in the past, high-temperature glasses, glass-ceramics, and crystalline ceramics are presently under consideration as second-generation waste forms. The crystalline titanate ceramic Synroc, among others, has exhibited good performance as a candidate second-generation waste form.

The purpose of this study was to evaluate the leaching performance of an Australian-prepared Synroc-C (for commercial waste) by comparison with a wel1documented borosilicate glass, MCC 76-68, using several test methods. The selection of leach tests was intended to focus on measurements, such as saturation values and initial leach rates, that can be applied to repository transport models as well as be used to compare waste forms.

The 76-68 glass used in this work contained 33 wt\% PW-8a waste calcine and 4.16 wt\% U02, while the Synroc-C contained 10 wt\% PW-4b calcine and 0.49 wt $\%$ U02. Uranium was the only radioactive species in these tests. Two test procedures were used: a modified MCC-1 procedure using monolithic test specimens and the MCC -3 procedure using specimens crushed to $-40 /+80$ mesh $(-420 /+177 \mu \mathrm{m})$ to obtain an unreacted high surface area. The tests were conducted at $90^{\circ} \mathrm{C}$ and $150^{\circ} \mathrm{C}$ in silicate water $\left(0.002 \mathrm{M} \mathrm{NaHCO}_{3}, 0.001 \mathrm{M} \mathrm{SiO2)}\right.$ with a pH of 8.67 and brine $(0.65 \mathrm{M} \mathrm{KCl}, 1.54 \mathrm{M} \mathrm{NaCl}, 1.22 \mathrm{M} \mathrm{MgC12})$ with a $\mathrm{pH}$ of 4.43 . The monolith tests were terminated at 28 days, but the MCC -3 powder tests were continued for up to 90 days. A11 leachate samples were filtered through 0.5-um filters, and samples from powder tests were also filtered through 1.8-nm filters to determine possible colloidal species. In addition to these tests, the temperature dependence on the initial leach rate was estimated between $90^{\circ} \mathrm{C}$ and $250^{\circ} \mathrm{C}$ in low surface area-to-volume (SA/V) tests conducted for 1 day.

The performance of Synroc-C relative to 76-68 glass in silicate water can be considered in terms of the release of $\mathrm{Ba}, \mathrm{Mo}, \mathrm{Cs}$, and $\mathrm{U}$. In monolith tests for up to 28 days, Ba concentrations found in solution from Synroc were less 
than $1 \mathrm{ppm}$ at $90^{\circ} \mathrm{C}$ and increased by about a factor of three at $150^{\circ} \mathrm{C}$. Ba is present in glass only as an impurity, and dissolution rates are consequently less than in Synroc. The concentrations of Mo, Cs, and $U$ in these monolith tests were normalized to the amount present in the waste form material. Normalized Mo released from Synroc $\left(2.0 \mathrm{~g} / \mathrm{m}^{2}\right)$ was about an order of magnitude lower than from glass at $90^{\circ} \mathrm{C}$. At $150^{\circ} \mathrm{C}$, however, normalized Mo was more than an order of magnitude higher in glass systems than in Synroc and indicated little temperature effect. Normalized Cs also showed very little temperature effect for Synroc with values of about $0.3 \mathrm{~g} / \mathrm{m}^{2}$, but $C s$ concentrations from glass systems were $20 \mathrm{~g} / \mathrm{m}^{2}$ at $90^{\circ} \mathrm{C}$ and $80 \mathrm{~g} / \mathrm{m}^{2}$ at $150^{\circ} \mathrm{C}$. At $90^{\circ} \mathrm{C}$, normalized $U$ concentrations were about $5.0 \mathrm{~g} / \mathrm{m}^{2}$ from glass monoliths but were about $0.1 \mathrm{~g} / \mathrm{m}^{2}$ for Synroc. At $150^{\circ} \mathrm{C}$, limited data suggest that normalized $U$ concentrations for Synroc may approach those for glass.

Results from the powder leach tests are reported in terms of concentrations, not normalized with respect to the amount present in the waste form material. U concentrations reached a maximum at 28 days and decreased to less than $10 \mathrm{ppb}$ for both Synroc and glass at 90 days, suggesting that a similar $U$-bearing reaction product may be forming for both materials. Comparisons of $0.5-\mu \mathrm{m}$ and $1.8-\mathrm{nm}$ filtrates indicated that part of the $U$ from glass may form colloids and that Ba from Synroc also tends to form small particles. Concentrations of $\mathrm{Ba}$ in silicate water at $90^{\circ} \mathrm{C}$ were near $5 \mathrm{ppm}$ in $0.5-\mu \mathrm{m}$ filtrates but were about $1 \mathrm{ppm}$ in 1.8-nm filtrates. Cs concentrations approached a steady state of about 10 ppm in glass systems but were about an order of magnitude lower in Synroc systems, suggesting that two different Cs phases are controlling dissolution. The Mo concentration reached a steady-state value of 10 ppm in Synroc powder tests at 90 days, but Mo release from glass was about a factor of five higher and did not exhibit steady-state behavior.

The temperature dependence for the initial release rate of Mo and Cs was estimated for both waste forms between $90^{\circ} \mathrm{C}$ and $250^{\circ} \mathrm{C}$ by conducting 1 -day dissolution tests at low SA/V ratios. In glass systems, initial release rates were one to three orders of magnitude higher than in Synroc. Activation energies determined from $C s$ release rates from glass were the same as those 
from Mo and had a value of $8.7 \mathrm{kcal} / \mathrm{mol}$, ignoring some slight curvature in the data. Activation energies determined from $C s$ release rates from Synroc were $3.2 \mathrm{kcal} / \mathrm{mol}$ while those based on Mo release were about $1.3 \mathrm{kcal} / \mathrm{mol}$, suggesting that $\mathrm{Cs}$ and Mo are associated with separate phases in Synroc.

In conclusion, Synroc-C appears to have about one order of magnitude better performance than a 76-68-type borosilicate glass, based on general leach test data. The concentrations of some radionuclides that typically form low solubility reaction products, such as uranium, may be controlled more by the type of reaction product formed than by release from waste forms. 



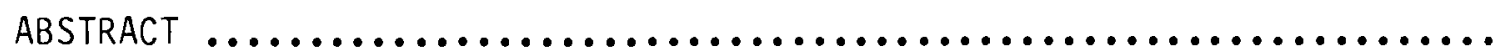

SUMMARY

INTRODUCTION

CONCLUSIONS

SELECTION OF LEACH TESTS

EXPERIMENTAL METHOOS

RESULTS AND DISCUSSION

SILICATE WATER LEACH TEST RESULTS

BRINE LEACH TEST RESULTS

APPENDIX A - LEACH TEST RESULTS FROM MCC - 1 AND MCC - 2 TESTS ON SYNROC-C AND 76-68 GLASS IN SILICATE WATER

APPENDIX B - LEACH TEST RESULTS FROM MCC-1 AND MCC-2 TESTS ON SYNROC-C AND 76-68 GLASS IN BRINE

APPENDIX C - LEACH TEST RESULTS FROM MCC - 3 TESTS ON SYNROC-C AND 76-68 GLASS IN SILICATE WATER

APPENDIX D - LEACH TEST RESULTS FROM MCC - 3 TESTS ON SYNROC-C AND 76-68 GLASS IN BRINE 
FIGURES

1 Final pH Values from Silicate Water Tests with Powders at

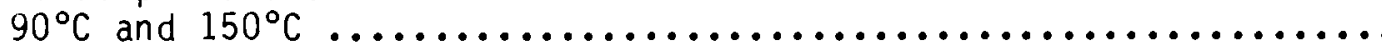

2 Ba Concentrations for Synroc-C and 76-68 Glass Monoliths in

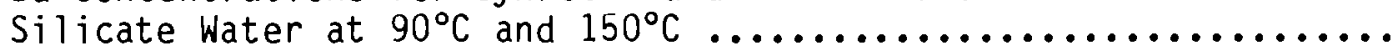

3 Normalized Cs Dissolution from Synroc-C and 76-68 Glass Monoliths in Silicate Water Tests at $90^{\circ} \mathrm{C}$ and $150^{\circ} \mathrm{C}$

4 Normalized Mo Dissolution from Synroc-C and 76-68 Glass Monoliths in Silicate Water Tests at $90^{\circ} \mathrm{C}$ and $150^{\circ} \mathrm{C}$

5 Normalized U Dissolution from Synroc-C and 76-68 Glass Monoliths in Silicate Water Tests at $90^{\circ} \mathrm{C}$ and $150^{\circ} \mathrm{C} \ldots \ldots \ldots \ldots$

$6 \mathrm{Ba}, \mathrm{Cs}$, and Mo Concentrations in 0.5- $\mathrm{m}$ and 1.8-nm Filtrates of Silicate Water from Synroc-C Powder Tests at $90^{\circ} \mathrm{C}$

$7 \mathrm{Ba}, \mathrm{Cs}$, and Mo Concentrations for Synroc-C and 76-68 Glass

Powders in $0.5-\mu \mathrm{m}$ Filtrates of Silicate Water at $90^{\circ} \mathrm{C}$

$8 U$ Concentrations from $0.5-\mu m$ and $1.8-n m$ Filtrates of Synroc-C

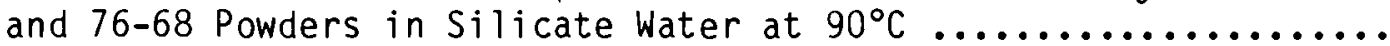

9 Cs Concentrations in $0.5 \mu \mathrm{m}$ Filtrates from Monolith and Powder Tests for Synroc-C and 76-68 Glass in Silicate Water at $90^{\circ} \mathrm{C} \mathrm{.....}$

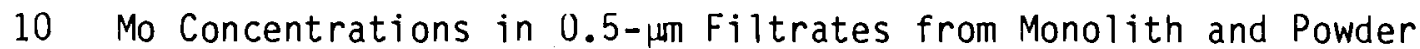
Tests for Synroc-C and $76-68$ Glass in Silicate water at $90^{\circ} \mathrm{C} . .$. .

11 Mo Concentrations in 0.5- $\mu \mathrm{m}$ Filtrates from Monolith and Powder Tests for Synroc-C and $76-68$ Glass in Silicate water at $150^{\circ} \mathrm{C} . .$.

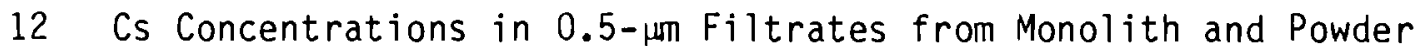
Tests for Synroc-C and 76-68 Glass in Silicate water at $150^{\circ} \mathrm{C} \ldots$

13 Temperature Dependence of Mo and Cs Forward Dissolution Rates Between $90^{\circ} \mathrm{C}$ and $250^{\circ} \mathrm{C}$ for Synroc-C and $76-68$ Glass

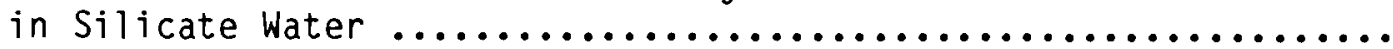




\section{$\underline{\text { TABLES }}$}

1 Compositions of U-Doped 76-68 Glass and Synroc-C ............. 10

2 Leachate Composition Changes Due to Sorption on Container

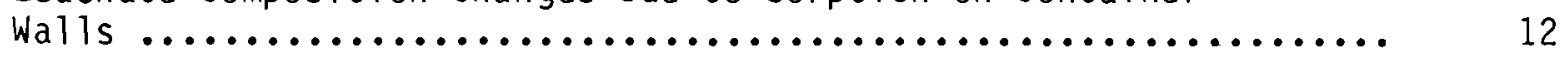

3 MCC -1 and MCC -2 Brine Leach Data ........................... 27

4 MCC-3 Brine Leach Data ................................. 27 


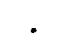

.

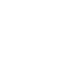




\section{INTRODUCTION}

Both glass and crystalline ceramic materials are being developed as waste containment forms for nuclear fuel reprocessing wastes and are under consideration along with unreprocessed spent fuel for disposal in geologic repositories. Excluding direct disposal of unreprocessed spent fuel (which is also being considered as a viable waste form), glass has been developed to the greatest extent as a high-level nuclear waste form, while ceramic materials have received less attention. Over the last 15 years, several types of ceramic waste forms such as supercalcine, Synroc, and various glass-ceramics have been investigated as alternatives to glass (Casey 1978; Chikalla and Mendel 1979). Some of these materials are being reconsidered as second-generation waste forms because they show promise of having better leaching and corrosion resistance than current waste forms.

The leaching behavior of a Synroc composition designated Synroc-C (supplied by the Australia Atomic Energy Commission) is evaluated in this report as a possible second-generation waste form. These results can be compared with results from leach tests on other second-generation waste form candidates such as high alumina glass (Bunnel1, Maupin, and Oma 1986) and sphene glass-ceramics (Hayward et al. 1986). This evaluation was conducted by Pacific Northwest Laboratory $(P N L)(a)$ under the Nuclear Waste Treatment Program.

The general concept of radionuclide containment by crystalline ceramic waste forms involves a choice of crystalline phases capable of accommodating long-lived radionuclides in durable crystalline phases that have low solubility products. Because reprocessing waste streams are chemically complex, it is necessary that crystalline structures be relatively open so that several kinds of ions representing a moderate range of ionic radii and ionic charge can be contained as solid solution components. For fabrication purposes, waste loadings, and phase stability, it is also desirable that the number of phases remain low. Thus, most ceramic waste forms are based on three to five silicate or titanate phases that have very low reactivity with repository environments.

(a) Operated for the U.S. Department of Energy under Contract DE-ACU6-76RLO 1830. 
For example, supercalcine is a silicate-based waste form (McCarthy and Davidson 1975), while Synroc-C is a titanate-based waste form (Ringwood 1978). Unless a glass-ceramic is specifically desired, fabrication methods for ceramic waste forms are generally directed towards producing nearly complete crystallinity in products that approach theoretical density as closely as possible.

In contrast to ceramic waste forms, isolation of radionuclides in glass structures is based on the ability of a structurally flexible glass network to contain the complete size range of radionuclides present in waste streams in a single matrix. In an idealized crystalline phase, a given radionuclide contained in a specific crystallographic site with highly directional bonding would be energetically more stable than the same radionuclide distributed in two or more sites, possibly including interstitial sites, in a random glass network. This kind of reasoning has lead to continued investigation of ceramic waste forms because their potential durability may exceed that of glass.

The structural differences between glass and crystalline ceramic waste forms as well as the differences in waste loading and radionuclide containment concepts require that appropriate methods of waste form evaluation be selected to insure equitable comparison. Differences in matrix dissolution mechanisms between crystalline and glass materials of the same composition may also affect leach model development (Shade 1981). Leach tests conducted during waste form development are typically short-term tests that compare release rates of elements normalized to the waste form composition. This approach may be appropriate for ranking waste form compositions within a single waste form type (such as glass) but may not be adequate to characterize diverse types of waste forms representing broad ranges in waste loadings. Moreover, the release rate of elements from a waste form is only one parameter required for evaluating waste forms in a repository environment and may not be as important as other factors, some site-related, such as molecular diffusivity, groundwater flow rate, or the presence of colloid-forming components from the waste package system and repository rock (Zavoshy, Chambre, and Pigford 1985). 


\section{CONCLUSIONS}

The following conclusions are based on the results of leach tests of Synroc-C and 76-68 glass:

- The dissolution rates of comparable elements such as Cs and Mo from Synroc-C are about an order of magnitude less than from 76-68 glass.

- A probable source of elements leached from Synroc-C is from an intergranular amorphous phase rather than crystalline phases.

- Elements such as $C s$ and Mo reach saturation as a function of the surface-area-to-volume (SA/V) ratio more rapidly for Synroc samples than for glass. The activation energies associated with dissolution of these elements from Synroc are also low.

- The relative leaching behavior of Synroc-C with respect to 76-68 glass in brines is about the same as in silicate water, which is usually about an order of magnitude difference in concentration for comparable elements such as Cs and Mo.

- Uranium dissolution from Synroc-C and 76-68 glass may be controlled more by the formation of reaction products than by dissolution rates from waste forms. 



\section{SELECTION OF LEACH TESTS}

The selection of an appropriate series of leach tests to evaluate Synroc-C was based on a desire to recognize waste form interactions with repository components and to provide measurements applicable to current radionuclide transport models. It was also desired to utilize some of the leach test methods developed by the Materials Characterization Center (MCC). Accordingly, modified versions of MCC-1 (MCC 1981) and MCC-3 (MCC 1984), using monolithic and powdered tests specimens, respectively, were selected along with an additional test designed to determine the forward-direction leach rate and the temperature dependence on the forward rate. To at least symbolically recognize repository interactions, only two of the three MCC solutions (MCC 1981) were used as leachates: a low-ionic-strength sodium bicarbonate $\left(0.002 \underline{M} \mathrm{NaHCO}_{3}\right)$-silicate $\left(0.001 \mathrm{M} \mathrm{SiO}_{2}\right)$ solution and a brine $\left.(0.65 \mathrm{M} \mathrm{KCl}, 1.54 \underline{\mathrm{M} \mathrm{NaCl}}, 1.22 \mathrm{M} \mathrm{MgCl})_{2}\right)$. The third MCC solution, deionized water, was not used. The silicate water was used to represent groundwater water types associated with crystalline aluminosilicate rock environments; the brine is a simplified representative of fluids from salt formations.

The results from these types of tests can be used to evaluate waste forms in terms of transport models developed to predict radionuclide migration rates in repository systems. One such model assumes that elements released from waste forms become saturated in a narrow zone adjacent to the waste form or at the waste form surface and that transport is limited by molecular diffusion in a low flow system (Chambre, Zavoshy, and Pigford 1982). Saturation values, such as might be expected from high SA/V ratio powder tests (MCC-3), are required for this model.

In an extension of this model (Zavoshy, Chambre, and Pigford 1985), two processes were considered. In one case, dissolved waste components migrate away from the waste form surface faster than the dissolution rate; thus, saturation is not attained. This situation might occur in a relatively fast flowing system and has been referred to as a surface-reaction-controlled 
process (Berner 1978). The rate-limiting step in this case is the forward dissolution rate, which is generally assumed to be first order with respect to matrix elements.

In the other case, radionuclide transport is limited by molecular diffusion of dissolved components away from the surface of the waste form or by diffusion plus convection in a flowing system. Dissolved components become saturated at the waste form surface and their release rate is referred to as transport controlled (Berner 1978).

To determine which of these two processes may be dominant in a given system, a "flux ratio," $R$, has been defined as follows (Zavoshy, Chambre, and Pigford 1985):

$$
R=\frac{\text { Forward dissolution rate per unit area }}{\text { Diffusive/convective mass transfer rate }}
$$

When $R$ is less than 1 , the dissolved components migrate away from the waste form surface faster than they can be replenished by dissolution so that saturation is not attained and the system is surface reaction controlled. This situation would be expected where the groundwater flow rate exceeds the dissolution rate of components from the waste form. When $R$ is greater than 1 , probably a more likely case, concentrations of dissolved components are at saturation and the release rate becomes transport controlled. This situation could occur under low flow rates or near static conditions.

The following analytical expression for the flux ratio has been derived (Zavoshy, Chambre, and Pigford 1985):

$$
R=\frac{\left(J_{0}\right)\left(r_{0}\right)}{(e)(D)\left(C_{s}\right)}
$$

where $J_{0}=$ forward dissolution rate

$$
r_{0}=\text { waste form radius }
$$




$$
\begin{aligned}
e & =\text { porosity of the surrounding medium } \\
D & =\text { liquid diffusion coefficient } \\
C_{S} & =\text { saturation value (or solubility) of a component. }
\end{aligned}
$$

This transport model utilizes relative values of waste form dissolution rates and groundwater flow rates to evaluate controls on waste form dissolution. The required variables for determining which of these two rates are dominant are contained in the expression for the flux ratio. Two of these variables, the forward dissolution rate $\left(\mathrm{J}_{0}\right)$ and the saturation value $\left(\mathrm{C}_{\mathrm{S}}\right)$ can be obtained from an appropriate choice of waste form dissolution tests. This concept has served as the basis for the choice of tests used in this work, which emphasize attempts to experimentaliy evaluate $\mathrm{J}_{0}$ and $\mathrm{C}_{S}$. In addition, activation energies obtained from the temperature dependence of $\mathrm{J}_{0}$ will be used to provide an indication of the overall capability of materials to retain components. 


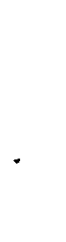




\section{EXPERIMENTAL METHODS}

The bulk compositions of U-doped 76-68 glass (ATM-1; Mellinger and Daniel 1984) and Synroc-C(a) are compared in Table 1 . The glass composition differs from Synroc-C both in terms of waste loading and in the type of calcine used to prepare the simulated waste. The 76-68 glass contained $33 \mathrm{wt} \% \mathrm{PW}-8 \mathrm{a}$ waste calcine and $4.16 \mathrm{wt} \%$ depleted $\mathrm{U0}_{2}$; the Synroc-C contained $10 \mathrm{wt} \% \mathrm{PW}-4 \mathrm{~b}$ waste calcine and $0.49 \mathrm{wt} \% \mathrm{UO}_{2}$. The Synroc-C was supplied as a large 500-g pellet, cut in half; and the glass was obtained in the form of bars. Test materials were prepared from these sources using methods described in the MCC -1 and MCC -3 test procedures (MCC 1981, 1984).

Monolith specimens were prepared by cutting small wafers, about 1 to $4 \mathrm{~cm}^{2}$ in surface area, using a diamond saw with water as the cutting fluid. The wafers were then cleaned ultrasonically. Powdered materials were prepared by crushing the source material until it passed through a 40-mesh (420- $\mu \mathrm{m})$ sieve, then collecting the $-40 /+80$-mesh $(-420 /+177-\mu \mathrm{m})$ fraction. The powdered fraction was cleaned ultrasonically in water to remove electrostatically adhered fine particles. Specific surface areas of these powders were estimated to be $45.9 \mathrm{~cm}^{2} / \mathrm{g}$ for the Synroc powders and $66.7 \mathrm{~cm}^{2} / \mathrm{g}$ for the $76-68 \mathrm{glass}$ powders.

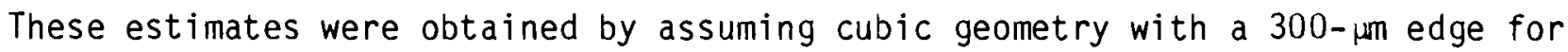
all particles and a density of $4.35 \mathrm{~g} / \mathrm{cm}^{2}$ for Synroc-C and $3.00 \mathrm{~g} / \mathrm{cm}^{2}$ for $76-68$ glass. Some preliminary leach testing comparing monoliths and powders at equal $S A / V$ ratios based on the above estimated surface areas yielded similar results, which provided confidence in the surface area estimates.

The MCC-1 tests using monolithic test specimens were conducted at SA/V ratios of $0.1 \mathrm{~cm}^{-1}\left(10 \mathrm{~m}^{-1}\right)$ for periods of up to 28 days. These tests were conducted at $90^{\circ} \mathrm{C}$ and $150^{\circ} \mathrm{C}$ in silicate water $(\mathrm{b})$ with a pH of 8.67 and in a brine ${ }^{(c)}$ with a $\mathrm{pH}$ of 4.43 . The MCC -3 tests were conducted for periods of up

\footnotetext{
(a) Nominal composition of Synroc-C was supplied with the 500-g sample that was shipped to PNL by W. J. Buykx of the Australian Atomic Energy Commission.

(b) $0.002 \underline{\mathrm{M} \mathrm{NaHCO}} 3,0.001 \mathrm{M} \mathrm{SiO}$.

(c) $0.65 \underline{\mathrm{M} \mathrm{KCl}}, 1.54 \underline{\mathrm{M} \mathrm{NaCT}}, 1.22 \underline{\mathrm{M}} \mathrm{MgCl}_{2}$.
} 
TABLE 1. Compositions of U-Doped 76-68 Glass and Synroc-C

Oxide 76-68 Glass, wt\% Synroc-C, wt\%

\begin{tabular}{|c|c|c|}
\hline $\mathrm{Ag}_{2} \mathrm{O}$ & 0.0 & 0.02 \\
\hline $\mathrm{Al}_{2} \mathrm{O}_{3}$ & 0.85 & 4.86 \\
\hline $\mathrm{B}_{2} \mathrm{O}_{3}$ & 8.55 & 0.0 \\
\hline $\mathrm{BaO}$ & 0.62 & 5.34 \\
\hline $\mathrm{CaO}$ & 2.11 & 9.99 \\
\hline $\mathrm{Cd} 0$ & 0.0 & 0.02 \\
\hline $\mathrm{CeO}_{2}$ & 0.97 & 1.22 \\
\hline $\mathrm{Cr}_{2} \mathrm{O}_{3}$ & 0.45 & 0.083 \\
\hline $\mathrm{Cs}_{2} \mathrm{O}$ & 0.77 & 0.83 \\
\hline $\mathrm{Fe}_{2} \mathrm{O}_{3}$ & 8.16 & 0.38 \\
\hline $\mathrm{Gd}_{2} \mathrm{O}_{3}$ & 0.0 & 0.37 \\
\hline $\mathrm{La}_{2} \mathrm{O}_{3}$ & 5.07 & 0.0 \\
\hline $\mathrm{MoO}_{3}$ & 1.99 & 1.31 \\
\hline $\mathrm{Na}_{2} \mathrm{O}$ & 9.66 & 0.0 \\
\hline $\mathrm{Nd}_{2} \mathrm{O}_{3}$ & 1.61 & 1.55 \\
\hline $\mathrm{NiO}$ & 0.22 & 0.031 \\
\hline $\mathrm{P}_{2} \mathrm{O}_{5}$ & 0.60 & 0.17 \\
\hline Pd0 & 0.0 & 0.37 \\
\hline $\mathrm{RuO}_{2}$ & 0.0 & 0.75 \\
\hline $\mathrm{Rh}_{2} \mathrm{O}_{3}$ & 0.0 & 0.12 \\
\hline $\mathrm{TeO}_{2}$ & 0.0 & 0.19 \\
\hline $\mathrm{SiO}_{2}$ & 40.50 & 0.0 \\
\hline SrO & 0.46 & 0.27 \\
\hline $\mathrm{TiO}_{2}$ & 2.60 & 64.2 \\
\hline $\mathrm{UO}_{2}$ & 4.16 & 0.49 \\
\hline $\mathrm{Y}_{2} \mathrm{O}_{3}$ & 0.0 & 0.16 \\
\hline $\operatorname{Zn} 0$ & 4.34 & 0.0 \\
\hline $\mathrm{ZrO}_{2}$ & 1.88 & 7.37 \\
\hline Total & 95.57 & 100.09 \\
\hline
\end{tabular}


to 90 days at $S A / V$ ratios of $4.6 \mathrm{~cm}^{-1}$ for Synroc powders and $6.7 \mathrm{~cm}^{-1}$ for 76-68 glass powders with the same solutions and temperatures as the monolith specimens. In both types of tests, solution samples were collected after cooling to room temperature, $\mathrm{pH}$ values were measured, and the solutions were

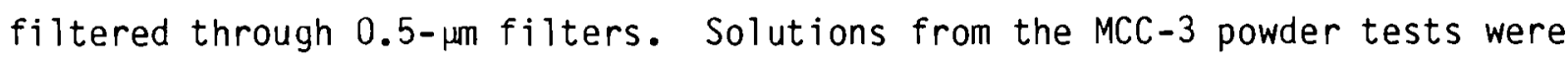
also filtered through 1.8-nm filters. Solutions from the monolith tests were acidified before analysis, and those from the powder tests were both acidified and diluted before analysis. All solution analyses were done by inductively coupled plasma spectroscopy (ICP); uranium analyses were done by laser fluorescence spectroscopy.

Some additional tests were done with monolith samples to determine if sorption on container walls might result in unacceptable leachate composition changes. In Table 2, Mo, $\mathrm{Cs}$, and $U$ concentrations in both silicate water and brine solutions are compared for $90^{\circ} \mathrm{C}$ and $150^{\circ} \mathrm{C}$ monolith tests. In one case, leachates were directly sampled after cooling to room temperature. In the second case, the solid sample was removed after the experiment, then the leachate was acidified in the leach container, which was returned to the oven overnight at the experimental temperature. There did not appear to be a large composition effect due to sorption on container walls; therefore, subsequent leachates were directly sampled. 
TABLE 2. Leachate Composition Changes Due to Sorption on Container Walls Results from $90^{\circ} \mathrm{C}, 28$-day, MCC-1 Tests

\begin{tabular}{|c|c|c|c|c|c|}
\hline Material (a) & Preparation (b) & Leachate $(c)$ & Mo, $\mathrm{ppm}$ & Cs, ppm & $\underline{U}, \mathrm{ppm}$ \\
\hline $\begin{array}{l}G \\
G \\
G \\
G\end{array}$ & $\begin{array}{l}D \\
D \\
H \\
H\end{array}$ & $\begin{array}{l}S \\
S \\
S \\
S\end{array}$ & $\begin{array}{l}2.28 \\
2.29 \\
2.29 \\
2.06\end{array}$ & $\begin{array}{l}1.70 \\
1.70 \\
1.70 \\
1.60\end{array}$ & $\begin{array}{l}1.21 \\
1.27 \\
1.43 \\
1.20\end{array}$ \\
\hline $\begin{array}{l}\mathrm{G} \\
\mathrm{G} \\
\mathrm{G} \\
\mathrm{G}\end{array}$ & $\begin{array}{l}D \\
D \\
H \\
H\end{array}$ & $\begin{array}{l}\mathrm{B} \\
\mathrm{B} \\
\mathrm{B} \\
\mathrm{B}\end{array}$ & $\begin{array}{l}1.79 \\
1.95 \\
1.84 \\
1.95\end{array}$ & $\begin{array}{l}0.88 \\
0.50 \\
0.75 \\
0.92\end{array}$ & $\begin{array}{l}0.0 \\
0.0 \\
0.13 \\
0.14\end{array}$ \\
\hline $\begin{array}{l}S \\
S \\
S \\
S \\
S \\
S\end{array}$ & $\begin{array}{l}D \\
D \\
D \\
H \\
H \\
H\end{array}$ & $\begin{array}{l}S \\
S \\
S \\
S \\
S \\
S\end{array}$ & $\begin{array}{l}0.18 \\
0.18 \\
0.19 \\
0.19 \\
0.18 \\
0.18\end{array}$ & $\begin{array}{l}0.045 \\
0.018 \\
0.039 \\
0.047 \\
0.026 \\
0.035\end{array}$ & $\begin{array}{l}0.002 \\
0.0 \\
0.002 \\
0.008 \\
0.003 \\
0.0\end{array}$ \\
\hline
\end{tabular}

Results from $150^{\circ} \mathrm{C}, 14$-day, MCC-2 Tests

$\begin{array}{llllll}G & D & S & 5.52 & 1.56 & 1.56 \\ G & D & S & 9.24 & 6.20 & 1.78 \\ G & H & S & 5.54 & 5.50 & 1.62 \\ G & H & S & 9.33 & 4.90 & 1.66 \\ S & & S & 0.25 & 0.066 & 0.0 \\ S & D & S & 0.25 & 0.075 & 0.0 \\ S & D & S & 0.40 & 0.072 & 0.001 \\ S & H & S & 0.28 & 0.066 & 0.002 \\ S & H & & & & \\ & & B & 0.37 & 0.0 & 0.0 \\ S & D & B & 0.41 & 0.0 & 0.17 ? \\ S & D & B & 0.42 & 0.0 & 0.07 \\ S & H & B & 0.41 & 0.0 & 0.05 \\ S & H & & & \end{array}$

(a) $G=76-68 \mathrm{glass} ; \mathrm{S}=$ Synroc $-\mathrm{C}$.

(b) $D=$ leachate sample taken directly after experiment; $H$ = leachate acidified in original container and held overnight at experimental temperature.

(c) $S=$ silicate water; $B=$ brine. 
RESULTS AND DISCUSSION

The durability of Synroc-C in silicate water systems as compared with 76-68 glass can be considered in terms of the dissolution of Ba, Cs, Mo, and $U$. These elements can be detected in leachate solutions, usually with reasonable precision, and are common to both waste forms. The amounts of $\mathrm{Cs}$ and Mo in Synroc-C are about the same as in 76-68, but $B a$ is a major component of Synroc while present in only minor amounts in glass (Table 1). Ba is the major cation in the Hollandite phase $\left(\mathrm{BaAl}_{2} \mathrm{Ti}_{6} \mathrm{O}_{16}\right)$ of Synroc, which also contains $\mathrm{Cs}$ in channel sites, while Mo is considered to partially substitute for $\mathrm{Ti}$ in the Perovskite phase $\left(\mathrm{CaTiO}_{3}\right)$ (Ringwood and Kesson 1979). U is assumed to be predominantly bound in the Zirconolite phase $\left(\mathrm{CaZrTi}_{2}{ }_{7}\right)$. These are the three major phases of Synroc (Ringwood and Kesson 1979).

Determining the dissolution rates of these four elements from the Synroc phases compared with their rates from glass, based on MCC-1-type tests and low $S A / V$ temperature-dependent tests, provides an indication of the durability of Synroc compared with glasses such as 76-68. The high SA/V MCC-3-type tests are intended to determine if saturation concentrations are approached for these elements.

Leach test results from silicate water systems are emphasized in this section because they are more extensive than results from brine systems. However, selected results from tests in brine systems are also presented in this

section. More detailed test results for monolith and powder specimens in both silicate water and brine systems are presented in the appendices.

\section{SILICATE WATER LEACH TEST RESULTS}

In a relatively unbuffered low-ionic-strength solution, the change in initial and final pH values during leaching is an approximate measure of waste form reactivity, which includes alkali-hydrogen ion exchange along with hydrolysis and dissociation of dissolved species. The initial pH of silicate water (8.6) increased to less than 9.0 in MCC-1 tests with both Synroc and glass monoliths for up to 28 days. All pH measurements were made at room temperature, and no distinct trends were apparent from the monolith tests. 
Measurements of $\mathrm{pH}$ for the high SA/V powder tests $\left(\mathrm{MCC}-3\right.$ ) at both $90^{\circ} \mathrm{C}$ and $150^{\circ} \mathrm{C}$ are shown in Figure 1. The maximum change in $\mathrm{pH}$ for all systems was from about 8.6 to 10.1 ; and, in most cases, replicate $\mathrm{pH}$ measurements were reproducible to less than a half a pH unit. In spite of these relatively small changes, some trends are apparent. In general, pH values increased with both time and temperature for both materials as the reaction progressed. This trend was expected for waste systems, especially glass systems (Grambow 1984; Shade and Strachan 1985). The increase in $\mathrm{pH}$, relative to initial values, observed for the 76-68 glass was greater than for Synroc and is a reflection of the higher reactivity of glass. A positive slope is shown at 56 and 90 days in Figure 1 for $150^{\circ} \mathrm{C}$ Synroc $\mathrm{pH}$ values, but these values may also be considered constant within the uncertainty of measurement. A constant $\mathrm{pH}$ for these time periods would be consistent with results, discussed later, that suggest several elements released from Synroc may have achieved saturation.

Results from the $\mathrm{MCC}-1$ tests at $90^{\circ} \mathrm{C}$ and $150^{\circ} \mathrm{C}$ are shown in Figures 2 through 5. Ba concentrations from monolith Synroc and glass specimens are given in Figure 2. These concentrations were not normalized because $\mathrm{Ba}$ is essentially an impurity in glass. Although the Ba concentrations were low, they do suggest a slight temperature dependence for Synroc. The source of $\mathrm{Ba}$ may be from the Hollandite phase or more likely from residual Ba in a less stable host.

Normalized concentrations of $\mathrm{Cs}$, Mo, and $U$ are given in Figures 3,4 , and 5. These data were normalized to the weight fraction of the element in the waste form. Both Cs and Mo release rates from glass and Synroc exhibited similar behavior. Based on the normalized concentrations of these elements from $90^{\circ} \mathrm{C}$ tests, release rates from glass were about an order of magnitude higher than those from Synroc. At $150^{\circ} \mathrm{C}$, these same rates were more than an order of magnitude higher for glass than for Synroc. Synroc also exhibited less temperature dependence on leach rates than glass, which supports the suggestion that $\mathrm{Cs}$ and Mo are in structurally dissimilar sites for the two materials. Normalized $U$ data from $M C C-1$ tests indicate that $U$ release rates in glass were more than an order of magnitude higher than in Synroc (Figure 5). There was little temperature dependence of $U$ release for both materials, but this may be 


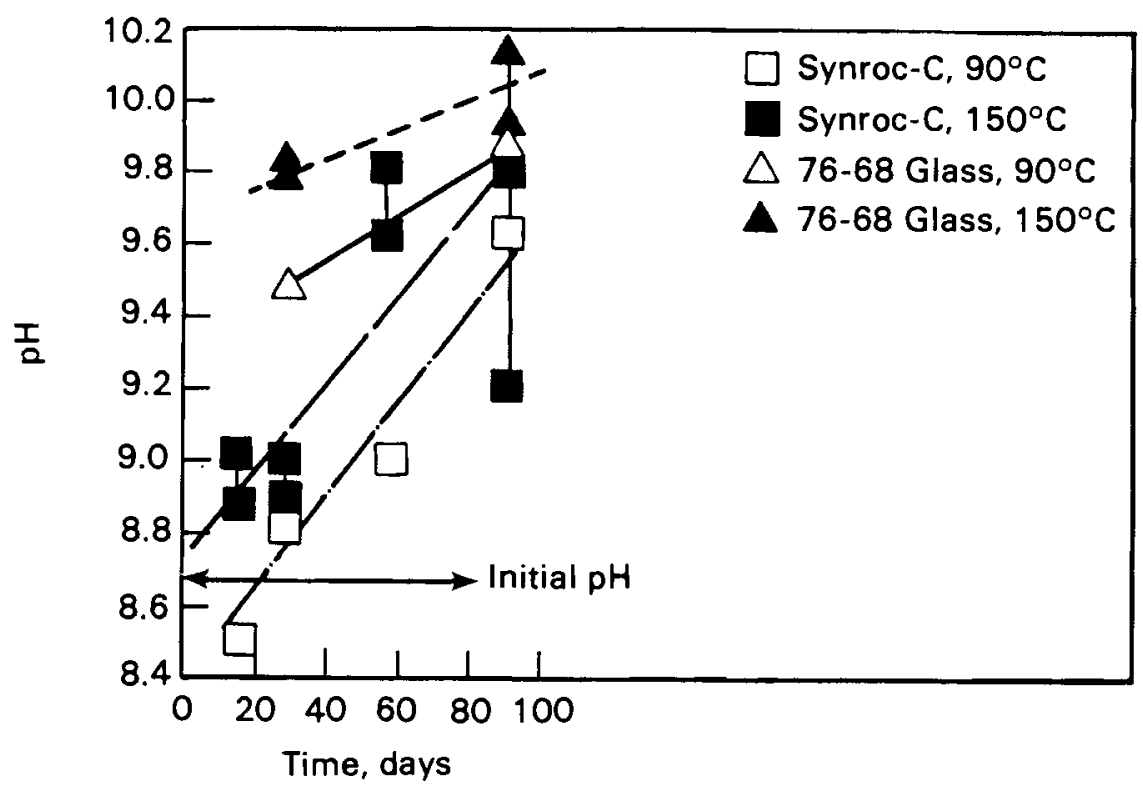

FIGURE 1. Final pH Values from Silicate Water Tests with Powders at $90^{\circ} \mathrm{C}$ and $150^{\circ} \mathrm{C}$

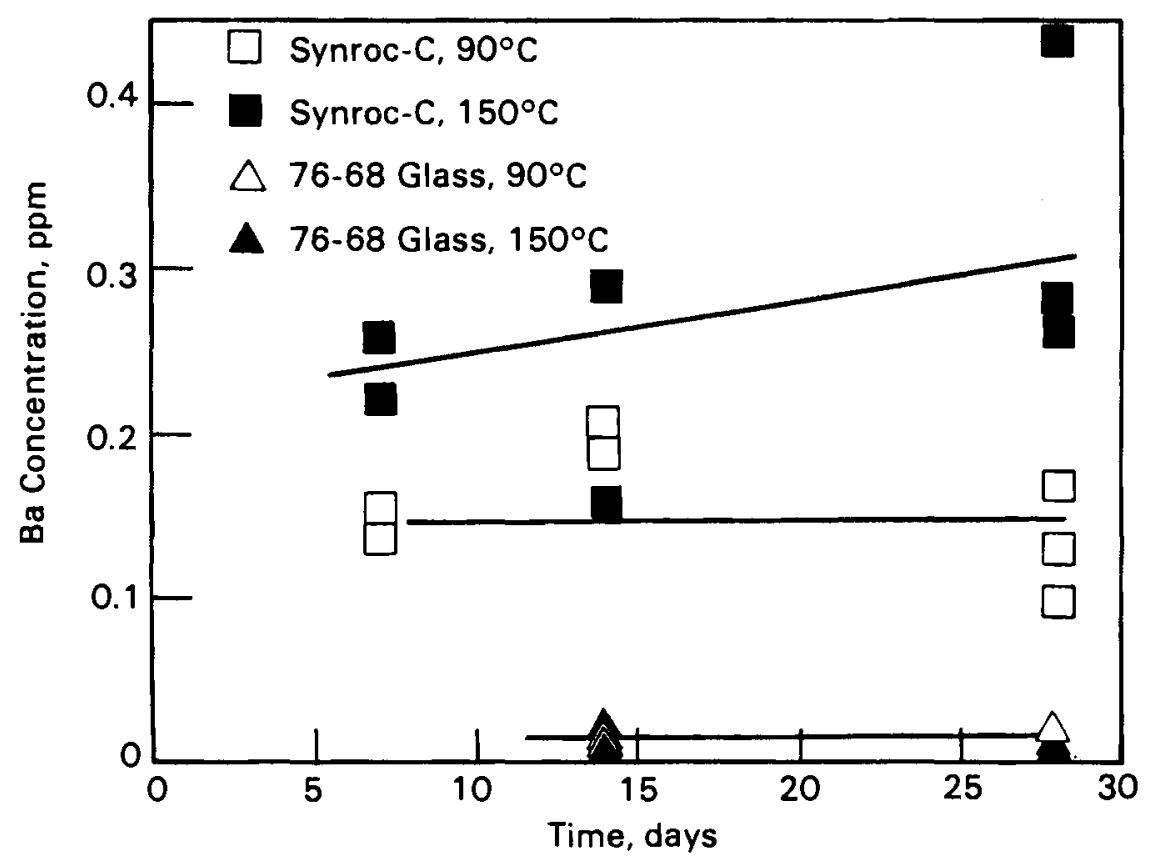

FIGURE 2. Ba Concentrations for Synroc-C and 76-68 Glass Monoliths in Silicate water at $90^{\circ} \mathrm{C}$ and $150^{\circ} \mathrm{C}$ 


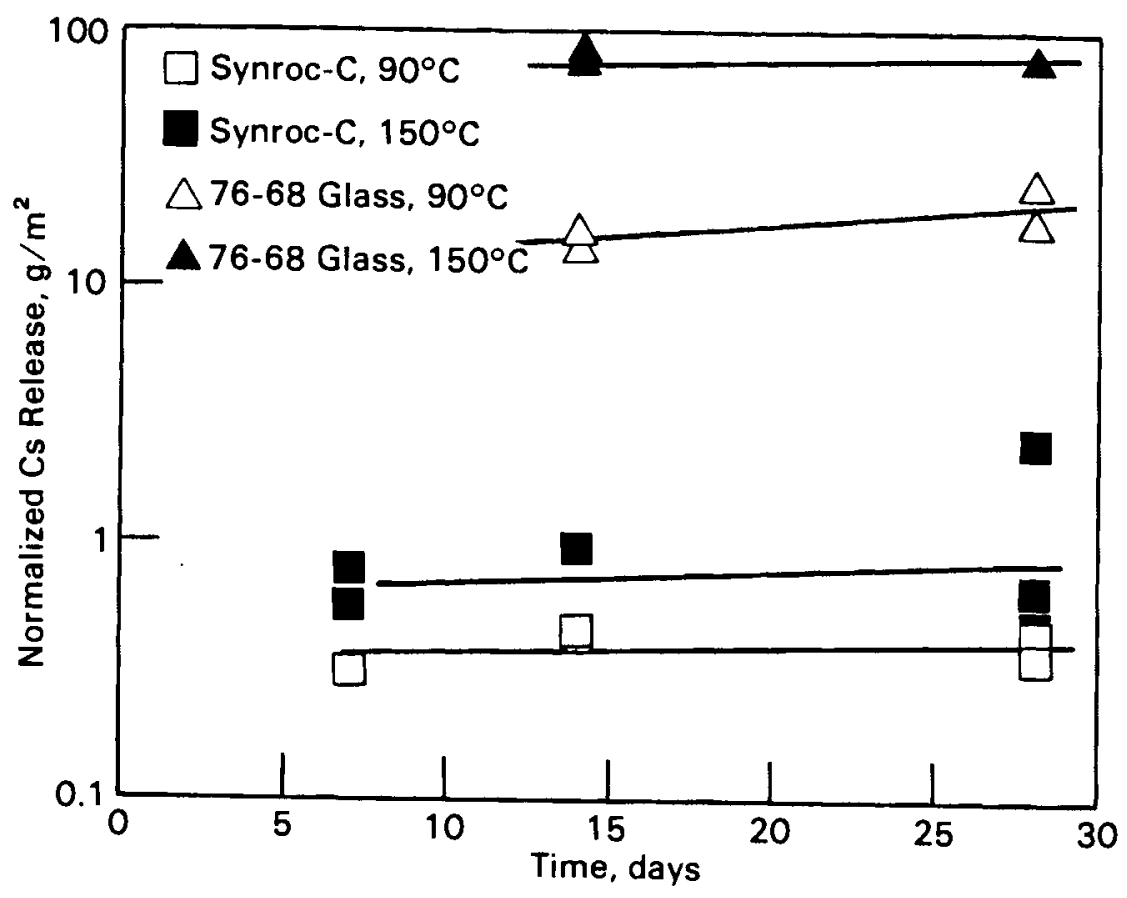

FIGURE 3. Normalized CS Dissolution from Synroc-C and 76-68 Glass Monoliths in Silicate water Tests at $90^{\circ} \mathrm{C}$ and $150^{\circ} \mathrm{C}$

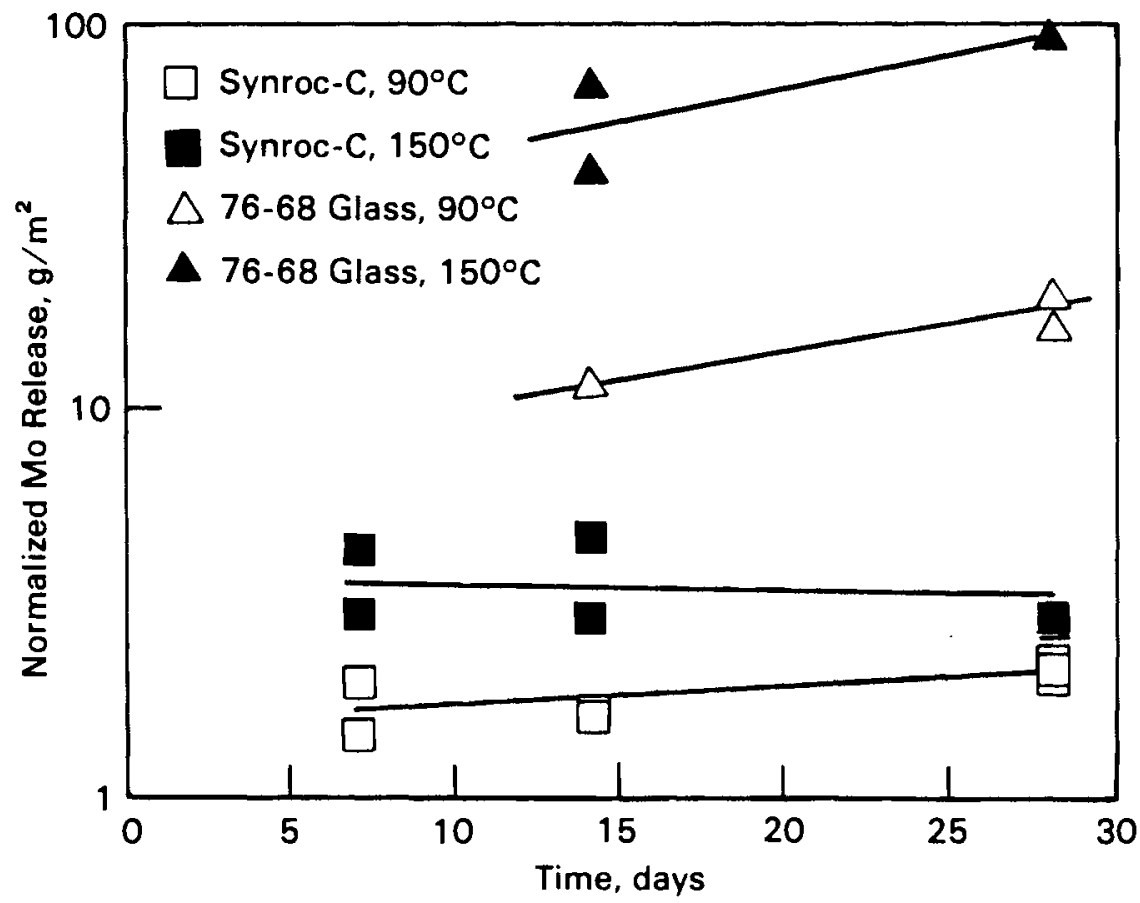

FIGURE 4. Normalized Mo Dissolution from Synroc-C and 76-68 Glass Monoliths in Silicate Water Tests at $90^{\circ} \mathrm{C}$ and $150^{\circ} \mathrm{C}$ 


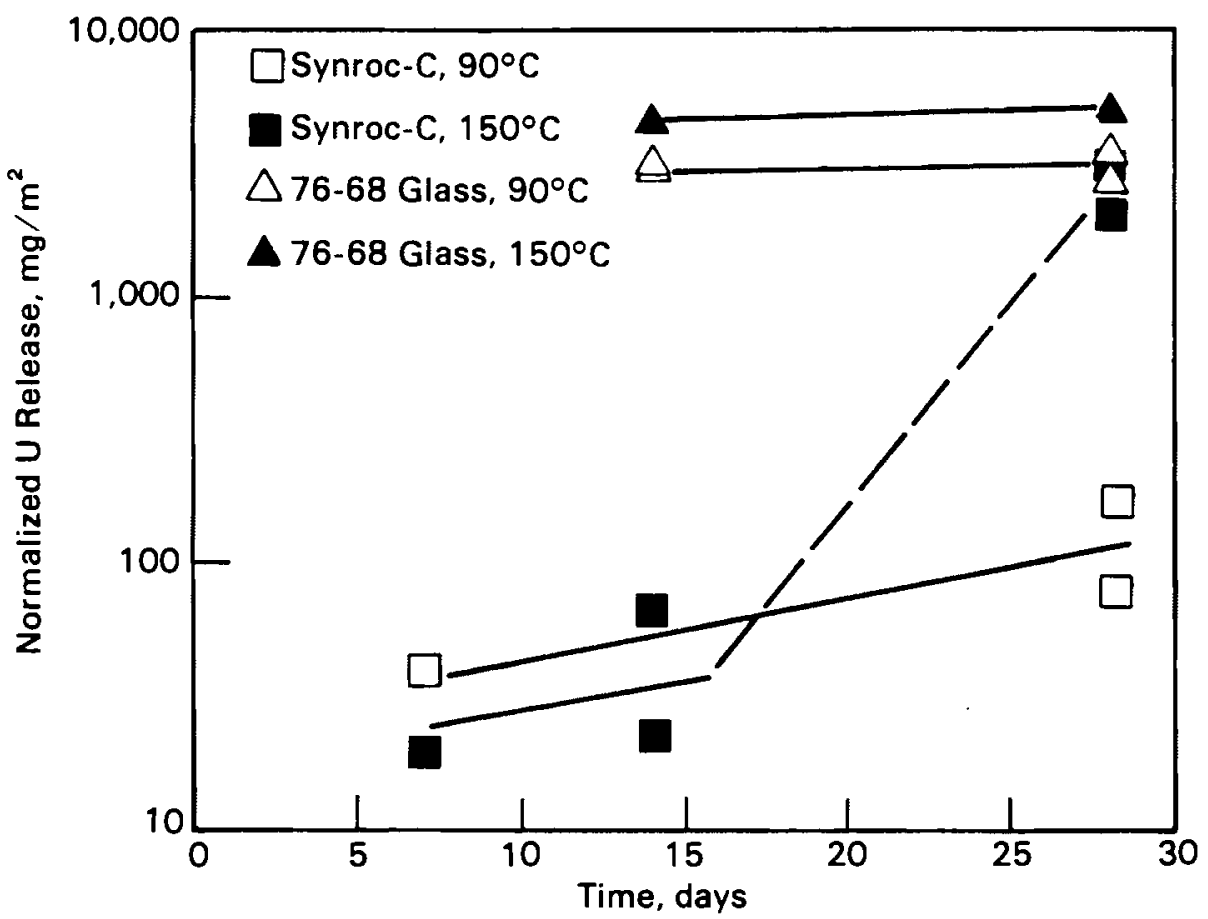

FIGURE 5. Normalized U Dissolution from Synroc-C and 76-68 Glass Monoliths in Silicate Water Tests at $90^{\circ} \mathrm{C}$ and $150^{\circ} \mathrm{C}$

partly caused by some precipitation during sample cooling. The high $U$ values at 28 days for the $150^{\circ} \mathrm{C}$ Synroc tests are uncertain because a replicate yielded low values. However, there seemed to be a slight increase in $U$ release with time for the Synroc tests; but $U$ release from glass may have become saturated at an early stage in the dissolution process. The $U$ concentrations observed from the dissolution of 76-68 glass that correspond to the normalized release values in Figure 5 are between 1 and $2 \mathrm{ppm}$. Concentrations of about 2 ppm were also measured for short (28-day) time periods in high surface area powder tests (see Figure 8 ). Within this range, $U$ concentrations were also measured in filtrates from other powder tests with 76-68 glass (Shade and Strachan 1986). Total $U$ concentrations of about $2.4 \mathrm{ppm}\left(10^{-5} \mathrm{~mol} / \mathrm{L}\right)$ were measured at $25^{\circ} \mathrm{C}$ in solubility studies of schoepite $\left(\mathrm{UO}_{3} \cdot 2 \mathrm{H}_{2} \mathrm{O}\right)$ between $\mathrm{pH}$ values of 9 to 10 (Krupka et al. 1985), which is in reasonable agreement with glass values considering the precision of $U$ analyses. Thus, a possible limiting control of $U$ concentrations in the early stages of dissolution may be a hydrated $U(V I)$ phase.

Results from the high SA/V powder tests (MCC-3) at $90^{\circ} \mathrm{C}$ are shown in $\mathrm{Fig}-$ ures 6 through 8 . These data are presented in terms of concentration units 


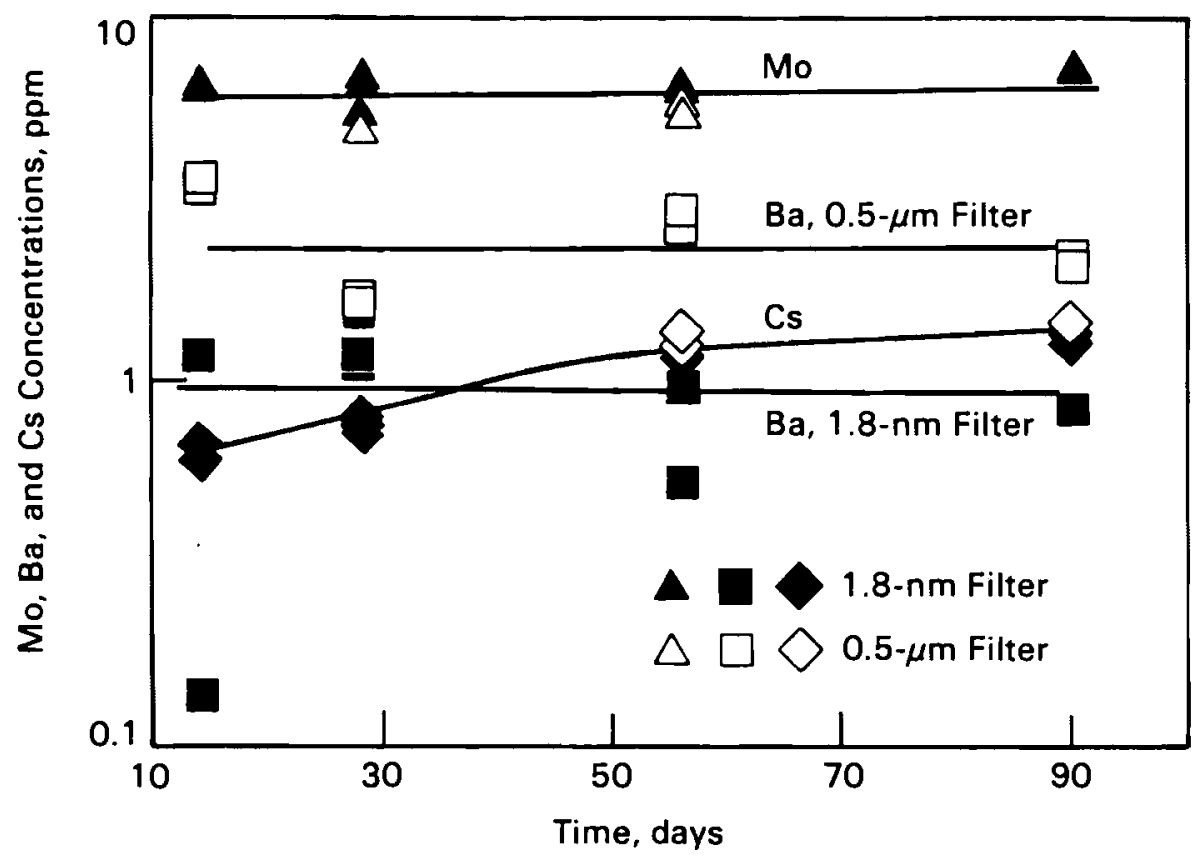

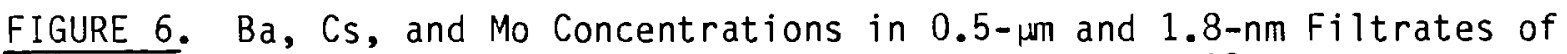
Silicate Water from Synroc-C Powder Tests at $90^{\circ} \mathrm{C}$

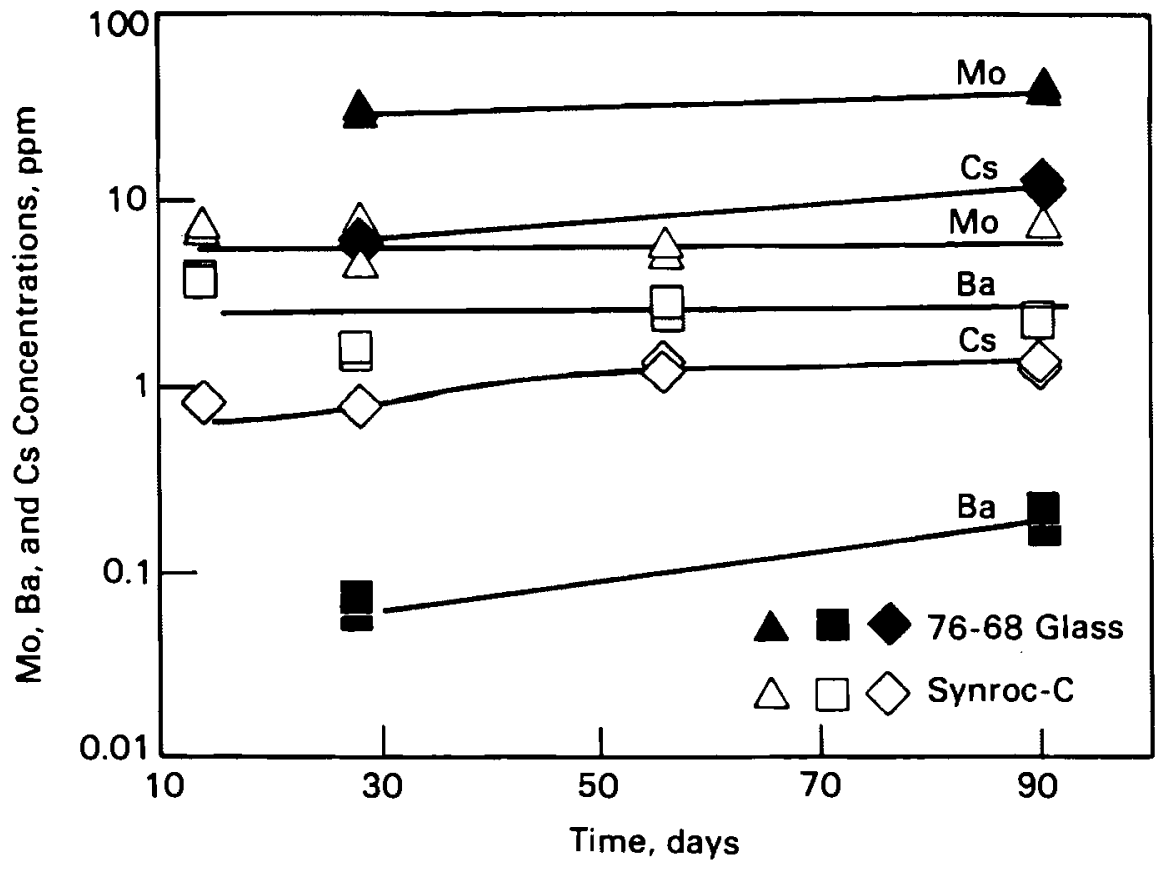

FIGURE 7. Ba, Cs, and Mo Concentrations for Synroc-C and 76-68 Glass Powders in $0.5-\mu \mathrm{m}$ Filtrates of Silicate water at $90^{\circ} \mathrm{C}$ 


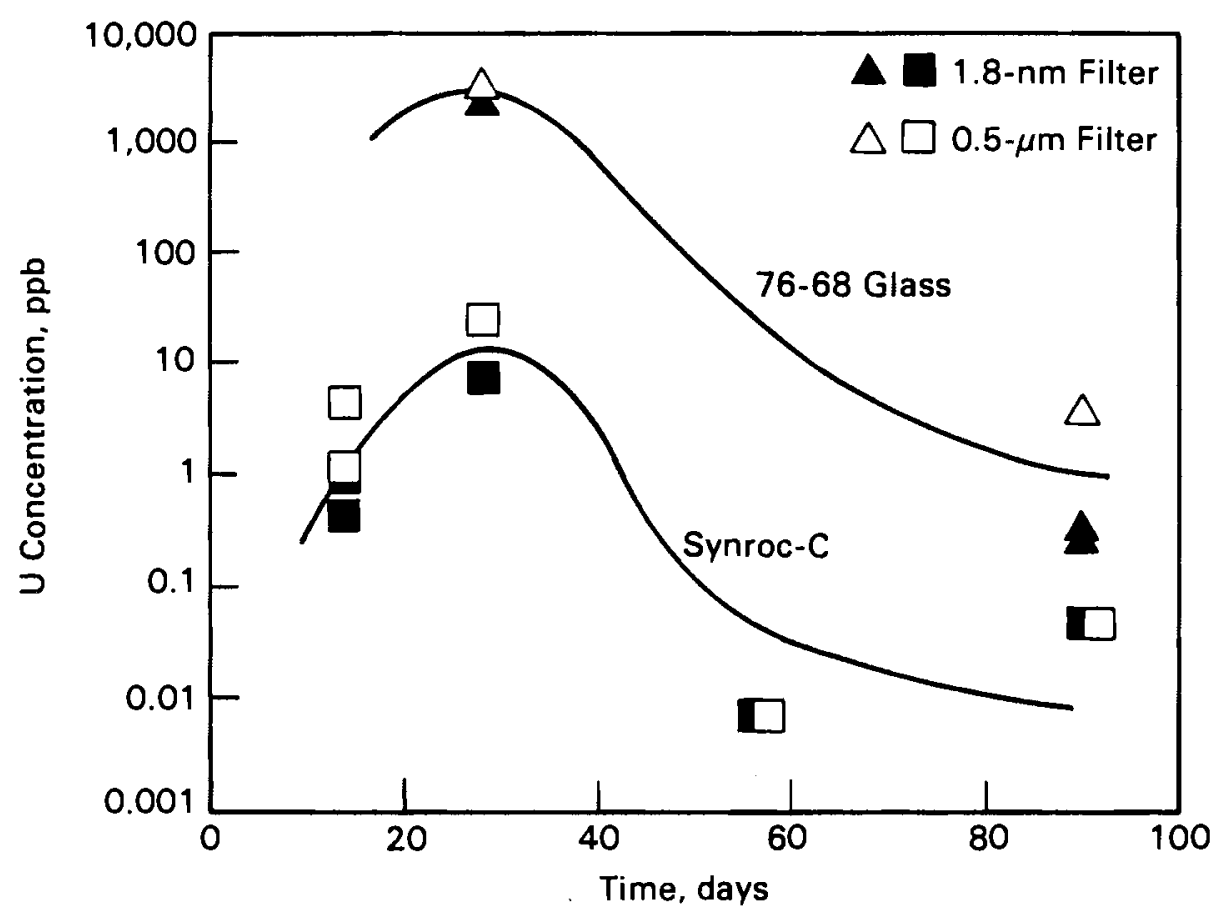

FIGURE 8. U Concentrations from $0.5-\mu \mathrm{m}$ and 1.8-nm Filtrates of Synroc-C and 76-68 Powders in Silicate Water at $90^{\circ} \mathrm{C}$

rather than normalized units because these tests measured saturation concentrations. For those who prefer other units, the $S A / V$ was $4.6 \mathrm{~cm}^{-1}$ for the Synroc tests and $6.7 \mathrm{~cm}^{-1}$ for the glass tests.

The Mo, Ba, and $\mathrm{Cs}$, concentrations in Synroc leachates after filtering through $0.5-\mu \mathrm{m}$ filters and then $1.8-\mathrm{nm}$ filters are shown in Figure 6 . These data indicate that $C s$ and Mo concentrations did not change after filtration, suggesting that these elements occur as dissolved species rather than particulates or colloids. It also appears that saturation has been achieved for Mo and closely approached for Cs. Within the scatter of the data, Ba seems to have reached saturation; but part of the total Ba exists in particulate form as might be expected at the relatively high $\mathrm{pH}$ values in these systems.

The concentrations of the same elements from 0.5-1m filtrates are compared for Synroc and glass systems in Figure 7. As indicated in earlier results, Mo and $C$ s concentrations were about an order of magnitude higher in 76-68 systems than in Synroc. On the basis of only two time periods, Mo and Cs concentrations seemed to increase with time for glass but may have reached saturation 
values for Synroc. Ba concentrations were lower in the glass than in Synroc; but $\mathrm{Ba}$ appears to have achieved saturation values in Synroc, which may suggest a steady-state condition with respect to Hollandite solubility or simply indicate removal of Ba from intergranular sites.

The $U$ data from these tests are shown in Figure 8 . Concentrations of $U$ were up to two orders of magnitude higher in glass than in Synroc, which is consistent with the results obtained for monolith tests. Maximum concentrations for both materials were observed at 28 days, but these values decreased by about two orders of magnitude at 90 days. At the $10 w U$ concentrations measured at 90 days, analytical precision is such that uncertainties in $U$ values are about an order of magnitude. In view of this analytical uncertainty, the trend of $U$ concentrations with time can be considered to eventually converge for both materials to a value lower than the maximum observed at 28 days. Controls on $U$ concentrations can then be interpreted in terms of sequential formation of $U$ solid phases. For example, if the high $U$ values observed at short time periods are assumed to be controlled by the solubility of a hydrated $U(V I)$ phase, then subsequent reaction of this phase with both alkali and silica (from either the initial liquid or the waste form) could result in the formation of an alkali uranium silicate such as sodium baltwoodite $\left[\mathrm{Na}_{2}\left(\mathrm{UO}_{2}\right)_{2}\left(\mathrm{SiO}_{3}\right)_{2}(\mathrm{OH})_{2} \cdot 5 \mathrm{H}_{2} \mathrm{O}\right]$ or weeksite $\left[\mathrm{K}_{2}\left(\mathrm{UO}_{2}\right)_{2}\left(\mathrm{Si}_{2} \mathrm{O}_{5}\right)_{3} \cdot 4 \mathrm{H}_{2} \mathrm{O}\right]$. Baltwoodite has been observed in experimental studies of U-bearing silicate water-basalt systems at temperatures as $10 \mathrm{w}$ as $60^{\circ} \mathrm{C}$ (Kelmers et al. 1986).

The CS and Mo concentrations from the high SA/V powder tests, the monolith tests, and the short-term (1-day) tests at $90^{\circ} \mathrm{C}$ and $150^{\circ} \mathrm{C}$ were combined in terms of $S A / V \times$ time as shown in Figures 9 through 12 . The $S A / V \times$ time parameter provides an indication of concentrations that might be expected in flow tests if the surface area divided by flow rate can be considered to be a reasonable approximation for this parameter. At high $S A / V \times$ time values, saturation concentrations can be determined, which provide $C_{j}$ values for the flux ratio (Zavoshy, Chambre, and Pigford 1985). Low SA/V $x$ time values (such as $\log S A / V \times$ time $=-1.0$ ) provide an approximation to the forward dissolution rate $\left(J_{0}\right)$. 


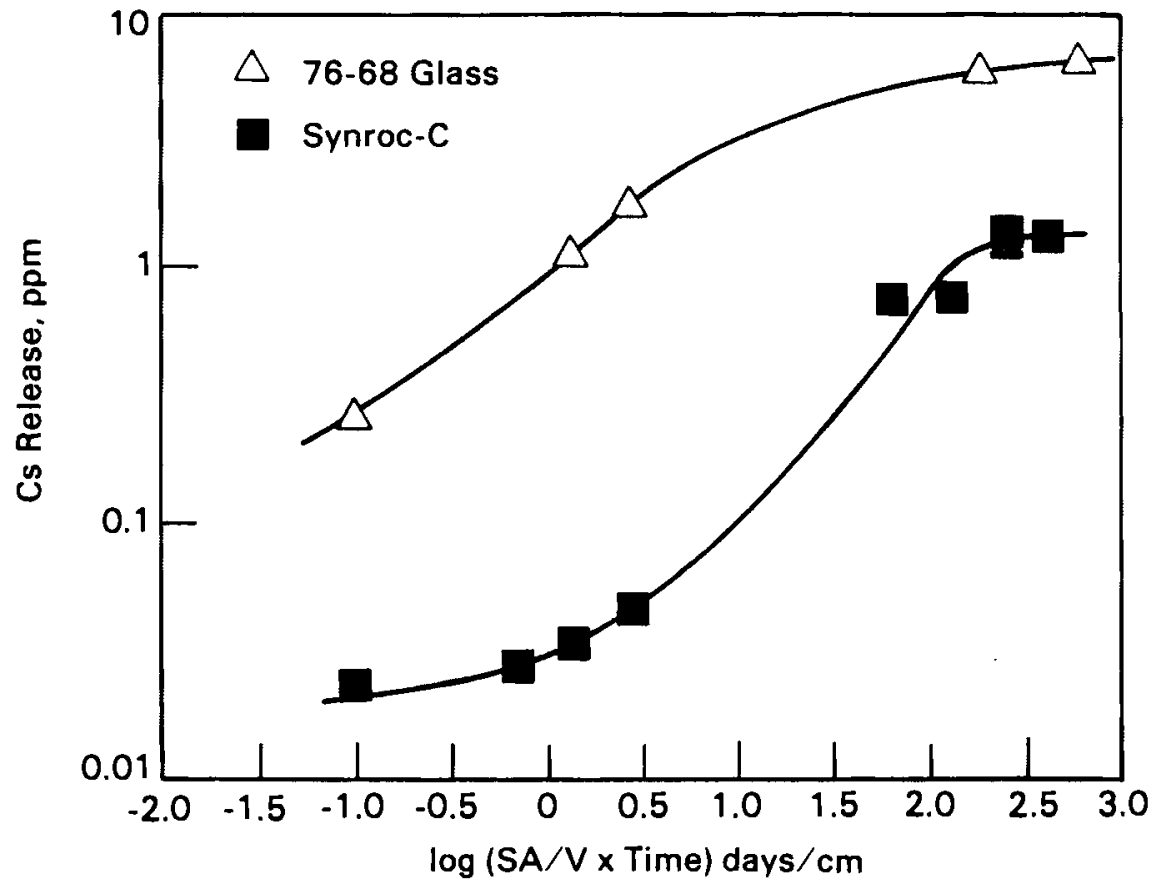

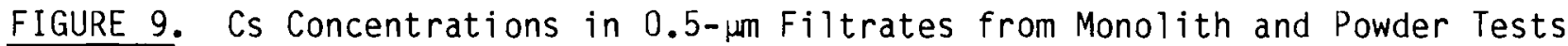
for Synroc-C and $76-68$ Glass in Silicate Water at $90^{\circ} \mathrm{C}$

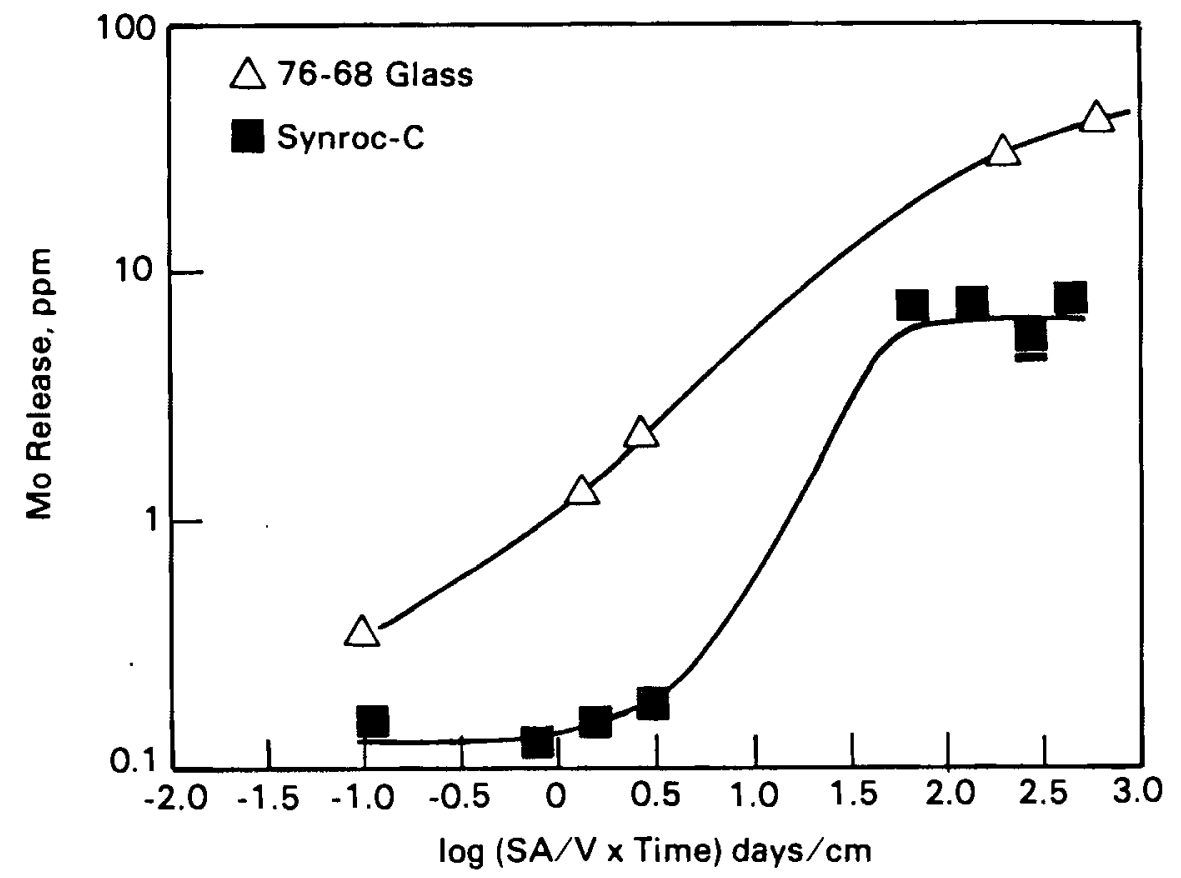

FIGURE 10. Mo Concentrations in $0.5-\mu \mathrm{m}$ Filtrates from Monolith and Powder Tests for Synroc-C and $76-68$ Glass in Silicate Water at $90^{\circ} \mathrm{C}$ 


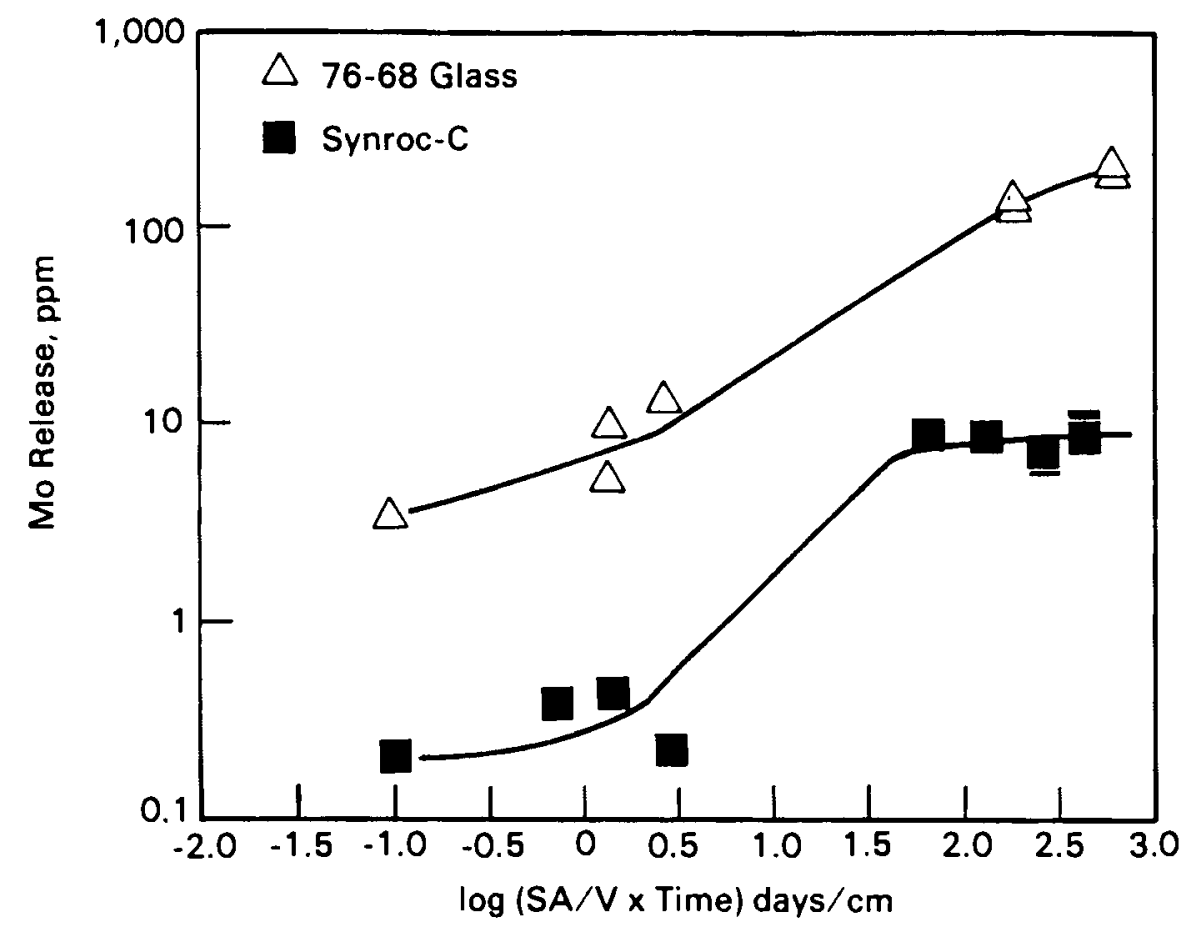

FIGURE 11. Mo Concentrations in 0.5- $\mu m$ Filtrates from Monolith and Powder Tests for Synroc-C and 76-68 Glass in Silicate water at $150^{\circ} \mathrm{C}$

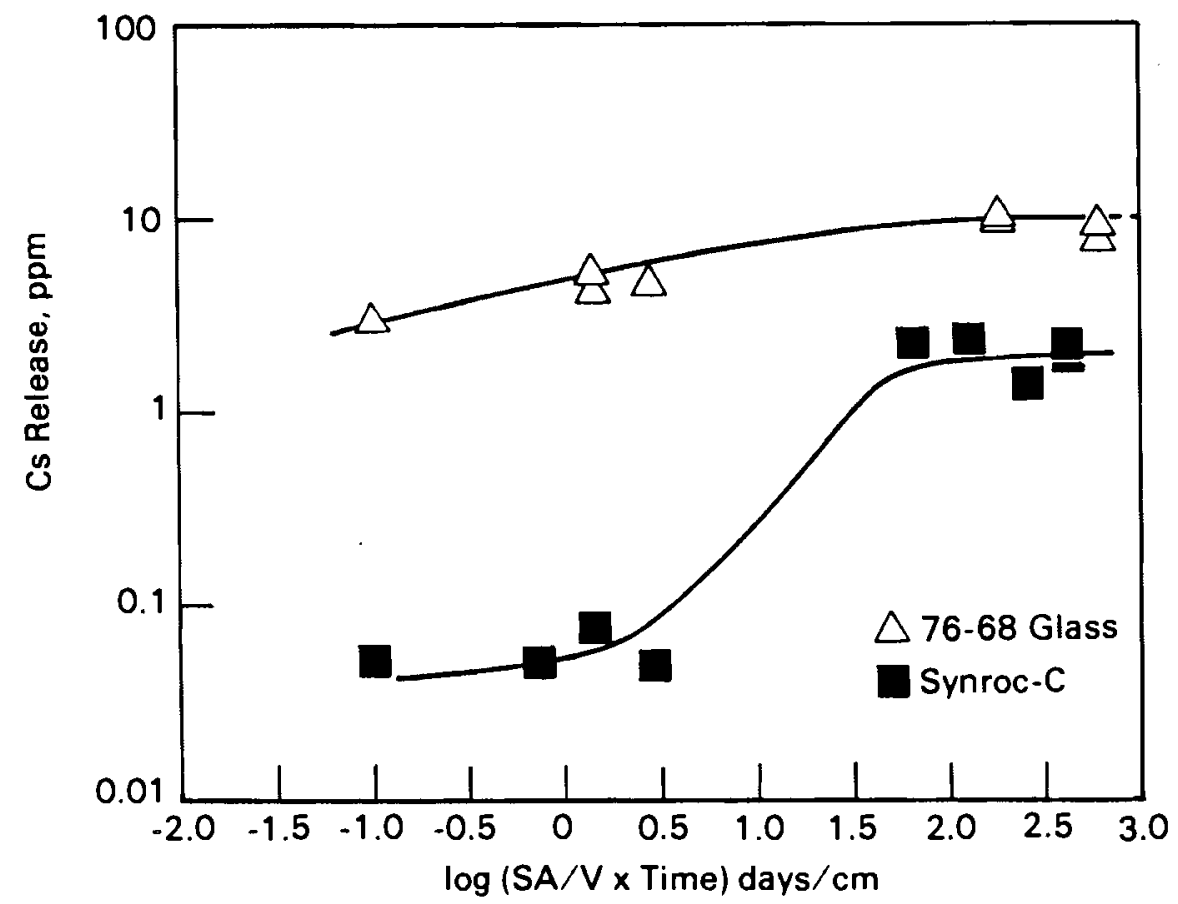

FIGURE 12. Cs Concentrations in 0.5- $\mu \mathrm{m}$ Filtrates from Monolith and Powder Tests for Synroc-C and $76-68$ Glass in Silicate water at $150^{\circ} \mathrm{C}$ 
Cs concentrations for Synroc and $76-68$ glass at $90^{\circ} \mathrm{C}$ (Figure 9) indicated an approach to saturation for both waste forms, although the Cs release from glass was almost an order of magnitude higher than from Synroc. If these saturation values can be considered as crude approximations of solubility values for Cs-bearing solids, the concentration differences support the fact that Cs in glass is chemically bound in different types of structural sites than in Synroc. This supposition is consistent with the assertion that $C s$ in Synroc is located in channels in the Hollandite phase (Ringwood and Kesson 1979) but is less localized in glass. It has been reported (Levins 1985) that Cs release from Synroc increases linearly with $S A / V$, with a slope near unity. At the $S A / V$ ratios investigated (about 4.0 to $250 \mathrm{~cm}^{-1}$ ), very little time dependence was observed at a given $S A / V$. The highest $S A / V$ value considered in the present work was $6.7 \mathrm{~cm}^{-1}$ (Figure 9); and after 56 days, Cs appeared to approach saturation at values near $1.0 \mathrm{ppm}$, which is in agreement with Levins (1985). The rapid increase in $C s$ with $S A / V$ ratios of Synroc described in Levins (1985) may be the result of increasing exposure of Cs-bearing channels in Hollandite as surface areas increase rather than by formation of a reaction product whose solubility controls Cs concentration. Another possibility is that the Cs released is from intergranular sites rather than from crystalline sites, so only residual Cs that is not structurally bound in crystals is dissolved. This type of mechanism has been suggested by Cooper et al. (1986) on the basis of high-resolution electron microscope examination of Synroc-C. Thus, as surface area increases, more intergranular sites are exposed. In the case of residual dissolution of intergranular Cs, a pulsed release would probably be expected rather than a continual release; thus, little time dependence would be observed.

Dissolution of Mo as a function of $S A / V \times$ time at $90^{\circ} \mathrm{C}$ is compared for 76-68 and Synroc in Figure 10. Mo concentrations were about an order of magnitude higher than $\mathrm{Cs}$ concentrations at this temperature, and Mo concentrations from glass were higher than those from Synroc by about the same amount. Mo saturation appears to have been attained for Synroc but not for glass, which may be the result of intergranular release of Mo as suggested for Cs. 
The forward-direction leach rate and saturation concentrations can be obtained from the data that are compiled in figures such as Figures 9 and 10. These data can be used to calculate transport-related parameters such as the flux ratio (Zavoshy, Chambre, and Pigford 1985), which was described previously. For example, the $C s$ flux ratio is calculated from the data in Figure 9 for Synroc and 76-68 glass assuming a canister radius $\left(r_{0}\right)$ of $0.44 \mathrm{~m}$ and a porosity (e) of 0.01 . At a value of $-1.0 \mathrm{day} / \mathrm{cm}$ for $\log S A / V \times$ time in Figure 9, the Cs concentrations are $0.03 \mathrm{ppm}$ for Synroc and $0.4 \mathrm{ppm}$ for 76-68 glass. The $S A / V$ ratio for both materials was $10 \mathrm{~m}^{-1}$ and the leach test was conducted for 1 day, so the forward leach rate $\left(j_{0}\right)$ was $0.003 \mathrm{~g} / \mathrm{m}^{2}$-day for Synroc and $0.04 \mathrm{~g} / \mathrm{m}^{2}$-day for glass. The saturation values $\left(C_{\mathrm{s}}\right)$ can be obtained in the region where $\log S A / V \times$ time is 2.5 day $/ \mathrm{cm}$ and is about $1.0 \mathrm{ppm}\left(\mathrm{g} / \mathrm{m}^{3}\right)$ for Synroc and about $8 \mathrm{ppm}\left(\mathrm{g} / \mathrm{m}^{3}\right)$ for glass. Using a diffusion coefficient (D) for cs of $3.4 \times 10^{-4} \mathrm{~m}^{2}$ /day and substituting these values into the flux ratio equation yields a Synroc flux ratio of $3.9 \times 10^{2}$ and a glass flux ratio of $6.5 \times 10^{2}$. Thus, under these conditions, both glass and Synroc exhibit flux ratios much greater than unity so that $C_{s}$ removal from both waste forms would probably be transport controlled by diffusive/convective processes.

Mo and $\mathrm{Cs}$ values at $150^{\circ} \mathrm{C}$ are shown in Figures 11 and 12 ; the trends are similar to those at $90^{\circ} \mathrm{C}$. The glass consistently yielded a greater temperature dependence than Synroc. At low SA/V $x$ time values, the data in Figure 11 suggest that $\mathrm{Cs}$ was nearly saturated for glass systems at $150^{\circ} \mathrm{C}$. Mo continued to dissolve from the glass at $150^{\circ} \mathrm{C}$ at high $S A / V \times$ time values and showed no indication of saturation.

The estimated forward leach rates for $C s$ and Mo from Synroc and 76-68 glass in the temperature range from 90 to $250^{\circ} \mathrm{C}$ are shown in Figure 13 . These elements were selected because they do not tend to form precipitates or colloidal species during cooling of dilute solutions. Cs and Mo determinations were made from tests in which the $S A / V$ for both materials was $0.1 \mathrm{~cm}^{-1}$ using the $-40 /+80$ mesh size. The tests were conducted in deionized water for $24 \mathrm{~h}$; thus, the $S A / V \times$ time value is $0.1 \mathrm{day} / \mathrm{cm}$. These parameters were selected to obtain measurable amounts of $\mathrm{Cs}$ and Mo at the lowest $S A / V \times$ time value possible and to avoid the occurrence of back reactions or precipitation. Another approach was 


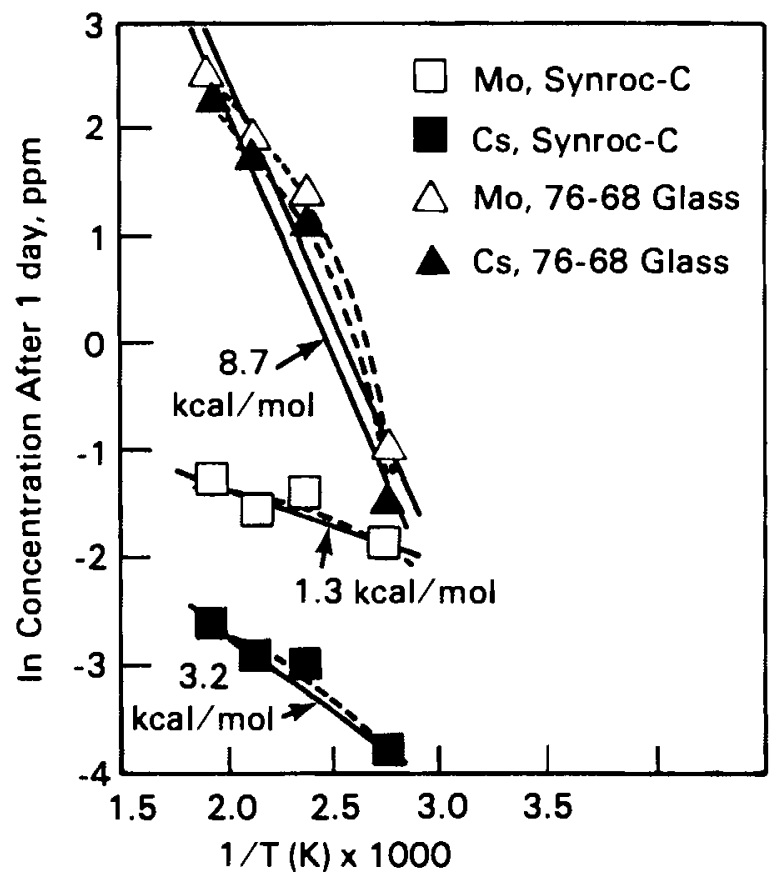

FIGURE 13. Temperature Dependence of Mo and CS Forward Dissolution Rates Between $90^{\circ} \mathrm{C}$ and $250^{\circ} \mathrm{C}$ for Synroc-C and $76-68 \mathrm{Glass}$ in Silicate Water

attempted in which the leach times were decreased in proportion to the temperature differences so that the shortest leach times occurred at the highest temperatures. Results from this approach were not satisfactory because Cs and Mo concentrations were near or below detection limits.

Measurements of glass leaching rates at different temperatures resulted in $\mathrm{pH}$ changes that increased, relative to initial pH values, at higher temperatures. The initial pH value for deionized water was about 6.0, and final values after 1 day were 8.6 at $90^{\circ} \mathrm{C}$ and 9.4 at $200^{\circ} \mathrm{C}$. This increase occurred in part because more of the hydrolyzable elements, such as $\mathrm{Na}$, were leached from the glass at higher temperatures than at lower temperatures. At higher temperatures, a greater fraction of the initial deionized water was in the vapor phase; thus, less liquid water was in contact with the waste form. Dissociation constants and water ionization constants are temperature dependent, but Cs and Mo values were determined at ambient temperature. These temperature effects are probably the dominant cause of the curvature exhibited by the data in Figure 13. The curvature was more pronounced in glass than in Synroc 
because more material was in solution and participated in hydrolysis reactions. These data are considered to represent an approximation of the forward leach rate, and the curvature is not considered to be indicative of a change in leaching mechanism with temperature. Samples obtained at temperature would probably provide better results, but equipment to do this was not available.

Activation energies were calculated from the Cs and Mo data in Figure 13 using slopes for the solid straight lines, which are considered to represent the actual data trends. Cs and Mo release rates from glass systems showed a nearly identical trend, which suggests they are released from structurally similar sites in glass. The activation energy of about $8.7 \mathrm{kcal} / \mathrm{mol}$ based on these elements is consistent with dissolution rates controlled by reactions at the glass surface (Lasaga and Kirkpatrick 1981). The low activation energies for Mo and Cs dissolution rates in Synroc of 1.3 and $3.2 \mathrm{kcal} / \mathrm{mol}$, respectively, as well as the low concentrations suggest that these elements may be released from intergranular or other sites in which they are not strongly bonded rather than from locations in crystalline phases. That is, the source of these elements might be from residual amorphous material remaining after waste form fabrication. The difference in activation energies also suggests that $\mathrm{Cs}$ and Mo are associated with sites that are nearly, but not exactly, chemically identical. The low activation energies are also consistent with the observation of unit increase of Cs dissolution with SA/V if it is assumed that increased amounts of interstitial amorphous material are exposed as the Synroc surface area increases and that apparent Cs saturation is controlled by the amount of interstitial material dissolved.

BRINE LEACH TEST RESULTS

A relatively small number of tests were conducted to investigate the dissolution behavior of Synroc in brines. Both monolith and powder tests were conducted, but fewer sampling periods were used than in the silicate water tests. A summary of the results for $\mathrm{Cs}, \mathrm{Mo}, \mathrm{Ca}, \mathrm{Ba}$, and $U$ is given in Tables 3 and 4. Additional brine test results are given in Appendices $B$ and $D$. In these brine tests, the final $\mathrm{pH}$ values did not change very much from the 
TABLE 3. MCC-1 and MCC-2 Brine Leach Data

\begin{tabular}{|c|c|c|c|c|c|c|}
\hline \multirow[b]{2}{*}{ Conditions } & \multirow{2}{*}{$\begin{array}{l}\text { Time, } \\
\text { days }\end{array}$} & \multicolumn{4}{|c|}{ Concentration, ppm } & \multirow[b]{2}{*}{$\underline{U}$ Concentration, $\mathrm{ppb}$} \\
\hline & & $\overline{C s}$ & Mo & $\mathrm{Ca}$ & $\mathrm{Ba}$ & \\
\hline Synroc-C, $90^{\circ} \mathrm{C}$ & $\begin{array}{l}14 \\
28 \\
28\end{array}$ & $\begin{array}{l}0.0 \\
0.0 \\
0.0\end{array}$ & $\begin{array}{l}0.32 \\
0.31 \\
0.31\end{array}$ & $\begin{array}{l}0.44 \\
0.90 \\
0.92\end{array}$ & $\begin{array}{l}0.50 \\
0.61 \\
0.59\end{array}$ & $\begin{array}{l}0.0 \\
0.0 \\
0.0\end{array}$ \\
\hline $76-68$ Glass, $90^{\circ} \mathrm{C}$ & $\begin{array}{l}28 \\
28\end{array}$ & $\begin{array}{l}0.75 \\
0.92\end{array}$ & $\begin{array}{l}1.80 \\
1.95\end{array}$ & $\begin{array}{l}2.5 \\
2.5\end{array}$ & $\begin{array}{l}0.96 \\
0.97\end{array}$ & $\begin{array}{l}130 \\
140\end{array}$ \\
\hline Synroc-C, $150^{\circ} \mathrm{C}$ & $\begin{array}{l}14 \\
14 \\
28\end{array}$ & $\begin{array}{l}0.0 \\
0.0 \\
0.0\end{array}$ & $\begin{array}{l}0.37 \\
0.41 \\
0.54\end{array}$ & $\begin{array}{l}0.67 \\
0.71 \\
0.91\end{array}$ & $\begin{array}{l}0.82 \\
0.97 \\
1.04\end{array}$ & $\begin{array}{l}70 \\
50 \\
0\end{array}$ \\
\hline $76-68$ Glass, $150^{\circ} \mathrm{C}$ & 28 & 4.0 & 8.4 & 11.5 & 4.08 & 2000 \\
\hline
\end{tabular}

TABLE 4. MCC-3 Brine Leach Data

\begin{tabular}{|c|c|c|c|c|c|c|}
\hline \multirow[b]{2}{*}{ Conditions } & \multirow{2}{*}{$\begin{array}{l}\text { Time, } \\
\text { days }\end{array}$} & \multicolumn{4}{|c|}{ Concentration, ppm } & \multirow[b]{2}{*}{$U$ Concentration, $\mathrm{ppb}$} \\
\hline & & Cs & Mo & $\mathrm{Ca}$ & $\mathrm{Ba}$ & \\
\hline Synroc-C, $90^{\circ} \mathrm{C}$ & $\begin{array}{l}28 \\
28 \\
90 \\
90\end{array}$ & $\begin{array}{l}0.73 \\
0.73 \\
1.50 \\
1.50\end{array}$ & $\begin{array}{l}9.54 \\
8.95 \\
7.87 \\
7.80\end{array}$ & $\begin{array}{l}1.16 \\
1.15 \\
4.04 \\
3.99\end{array}$ & $\begin{array}{l}7.27 \\
7.48 \\
6.38 \\
6.28\end{array}$ & $\begin{array}{l}0.03 \\
0.03 \\
0.05 \\
0.05\end{array}$ \\
\hline
\end{tabular}

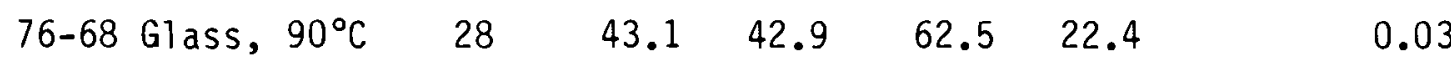

$\begin{array}{llllll}28 & 43.9 & 46.7 & 60.4 & 21.8 & 0.03\end{array}$

$\begin{array}{llllll}28 & 43.3 & 46.8 & 62.6 & 22.5 & 0.03\end{array}$

$\begin{array}{lrrrrrr}\text { Synroc-C, } 150^{\circ} \mathrm{C} & 28 & 1.4 & 12.0 & 4.75 & 16.2 & 0.03 \\ & 28 & 1.5 & 12.2 & 4.85 & 13.5 & 0.03 \\ & 90 & 1.5 & 10.8 & 10.6 & 13.9 & 0.05 \\ & 90 & 1.5 & 10.7 & 9.04 & 14.7 & 0.05 \\ 76-68 \mathrm{Gl} \text { ass, } 150^{\circ} \mathrm{C} & 28 & 117.0 & 10.2 & 153.5 & 55.4 & 0.03 \\ & 28 & 115.0 & 11.0 & 155.0 & 56.4 & 0.04 \\ & 28 & 122.0 & 10.5 & 149.3 & 53.7 & 0.03\end{array}$

initial values, at least within the precision of measurement (about one $\mathrm{pH}$ unit). Ca concentrations are listed in Tables 3 and 4 because they are readily measurable in brine tests but are generally low in silicate water tests. It is probable that $\mathrm{Mg}$ reactions with waste forms, such as the formation of $\mathrm{Mg}$ silicates in glass systems, led to Ca dissolution. 
Concentrations of elements dissolved from Synroc and glass monoliths at $90^{\circ} \mathrm{C}$ and $150^{\circ} \mathrm{C}$ are listed in Table 3. Detection limits are higher for many elements in brine systems than in silicate water, but the relative dissolution behavior of the two materials can be determined. In general, dissolution from glass was higher than from Synroc, usually by about an order of magnitude. It is presumed that the increased dissolution of $\mathrm{Ca}$ in brine systems compared with silicate water is the result of $\mathrm{Mg}$ reactions with the waste forms.

Concentrations of elements from powder tests are given in Table 4. The same general dissolution trend as observed for monoliths was apparent, with glass exhibiting higher dissolution rates than synroc. The $U$ values for glass are questionable and may reflect analytical problems. The high values for $\mathrm{Ba}$ dissolved from glass powders is somewhat surprising because it is inconsistent with other results. Consequently, these Ba values may also be questionable. In perspective, however, results from both the monolith and powder tests indicate that the dissolution behavior of Synroc relative to glass in brine systems is similar to that observed in silicate water systems. 


\section{REFERENCES}

Berner, R. A. 1978. "Rate Control of Mineral Dissolution Under Earth Surface Conditions." Am. J. Sci. 278:1235-1252.

Bunnel1, L. R., G. D. Maupin, and K. H. Oma. 1986. "High-Temperature Glasses for Nuclear Waste Isolation." PNL-SA-13606, presented at the American Ceramic Society Annual Meeting, Nuclear Waste Management Symposium, April 27-May 1, 1986, Chicago, Illinois.

Casey, L. A., ed. 1978. "High-Level Radioactive Solid Waste Forms." In Proceedings of a U.S. Nuclear Regulatory Commission Conference, Denver, Colorado, NUREG/CP-0005.

Chambre, P. L., S. J. Zavoshy, and T. H. Pigford. 1982. "Solubility-Limited Fractional Dissolution Rate of Vitrified Waste in Groundwater." Trans. Am. Nucl. Soc. 43:111.

Chikalla, T. D., and J. E. Mendel, eds. 1979. "Ceramics in Nuclear Waste Management." Presented at the American Ceramic Society Symposium, Cincinnati, Ohio, CONF-790420.

Cooper, J. A., et al. 1986. "Intergranular Films and Pore Surfaces in Synroc C: Structure, Composition, and Dissolution Characteristics." J. Am. Ceram. Soc. 69:347-352.

Grambow, B. 1984. "Geochemical Modeling of the Reaction Between Glass and Aqueous Solution." In Advances in Ceramics, Vol. 8, Nuclear Waste Management, Wicks and Ross, eds., pp. 478-481, American Ceramic Society.

Hayward, P. J., J. C. Tait, A. A. Carmichael, and J. P. M. Ross. 1986. "Source Term for Radionuclide Release from Sphere Glass-Ceramics." Presented at the American Ceramic Society Annual Meeting, Nuclear Waste Management Symposium, April 27-May 1, 1986, Chicago, Illinois.

Kelmers, A. D., W. D. Arnold, J. G. Blencoe, R. E. Meyer, G. K. Jacobs, and S. K. Whatley. 1986. Progress in Evaluation of Radionuclide Geochemical Information Developed by DOE High-Level Nuclear Waste Repository Site Projects. NUREG/CR-4236, ORNL/TM-9614, Vo1. 3, Oak Ridge National Laboratory, Oak Ridge, Tennessee.

Krupka, K. M., D. Rai, R. W. Fulton, and R. G. Strickert. 1985. "Solubility Data for U(VI) Hydroxide and $\mathrm{Np}$ (IV) Hydrous 0xide: Application of MCC-3 Methodology." Materials Research Society Symposium Proceedings, V. 44, Scientific Basis for Nuclear Waste Management, VIII, C. M. Jantzen et al., eds., pp. 753-760.

Lasaga, A. C., and R. J. Kirkpatrick. 1981. "Kinetics of Geochemical Processes." Rev. in Mineralogy, Vol. 8, Mineral. Soc. Am., Washington, D.C. 
Levins, D. M. 1985. Performance of Synroc Under Conditions Re levant to Repository Disposal. Australian Atomic Energy Commission, IAEA report (presented in Japan).

Materials Characterization Center. 1981. "MCC-1P Low Temperature Static Leach Test Method." In Nuclear Waste Materials Handbook, DOE/TIC-11400, National Technical Information Center, Springfield, Virginia.

Materials Characterization Center. 1984. MCC-3 Agitated Powder Leach Test. PNL-3990, Pacific Northwest Laboratory, Richland, Washington (test method submitted to Nuclear Waste Materials Handbook).

McCarthy, G. J., and M. T. Davidson. 1975. "Ceramic Nuclear Waste Forms I. Crystal Chemistry and Phase Formation." Am. Ceram. Soc. Bull. 54:782-786.

Mellinger, G. B., and J. L. Daniel. 1984. Approved Reference and Testing Materials for Use in Nuclear Waste Management Research and Development Programs. PNL-4955-2, Pacific Northwest Laboratory, Richland, Washington.

Ringwood, A. E. 1978. Safe Disposal of High-Level Nuclear Reactor Wastes: A New Strategy. Australian National University Press, Canberra.

Ringwood, A. E., and S. E. Kesson. 1979. "Immobilization of High-Level Waste in Synroc Titanate Ceramic." In Ceramics in Nuclear Waste Management,

T. D. Chikalla and J. E. Mendel, eds., CONF-790420, pp. 174-182.

Shade, J. W. 1981. "Comparison of Glass and Ceramic Leaching Behavior by Natural Analogs." Nucl. and Chem. Waste Mgmt. 2:219-228.

Shade J. W., and D. M. Strachan. 1985. "Effect of High Surface Area to Solution Volume Ratios on Waste Glass Leaching." PNL-SA-13679, submitted to American Ceramic Society.

Zavoshy, S. J., P. L. Chambre, and T. H. Pigford. 1985. "Mass Transfer in a Geologic Environment." Materials Research Society Symposium Proceedings, Vol. 44, Scientific Basis for Nuclear Waste Management, VIII, C. M. Jantzen et al., eds., pp. 311-322. 
APPENDIX A

LEACH TEST RESULTS FROM MCC-1 AND MCC-2 TESTS ON SYNROC-C AND 76-68 GLASS IN SILICATE WATERS 


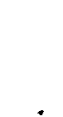


TABLE A.1. MCC -1 , Monolith, $90^{\circ} \mathrm{C}$, Silicate Water $(\mathrm{a})$

\begin{tabular}{|c|c|c|c|c|c|c|c|}
\hline & \multicolumn{7}{|c|}{ Material } \\
\hline & Synroc-C & Synroc-C & U 76-78 & Synroc-C & Synroc-C & U 76-68 & U $76-68$ \\
\hline $\begin{array}{l}\text { Size, cm } \\
\text { Fluid } \\
\text { Volume, mL } \\
\text { Initial pH } \\
\text { Final pH } \\
\text { Time, days }\end{array}$ & $\begin{array}{l}4.16 \\
\mathrm{Si} \mathrm{H}_{2} 0 \\
41.6^{2} \\
8.67 \\
8.96 \\
7\end{array}$ & $\begin{array}{l}3.97 \\
\mathrm{Si} \mathrm{H}_{2} \mathrm{O} \\
39.7^{2} \\
8.67 \\
8.82 \\
14\end{array}$ & $\begin{array}{l}4.11 \\
\mathrm{Si}^{1} \mathrm{H}_{2} \mathrm{O} \\
41.1^{2} \\
8.67 \\
8.94 \\
14\end{array}$ & $\begin{array}{l}4.17 \\
\mathrm{Si} \mathrm{H}_{2} \mathrm{O} \\
41.7^{2} \\
8.67 \\
8.70 \\
28\end{array}$ & $\begin{array}{l}4.34 \\
\mathrm{Si} \mathrm{H}_{2} \mathrm{O} \\
43.4^{2} \\
8.67 \\
8.85 \\
28\end{array}$ & $\begin{array}{l}4.06 \\
\mathrm{Si} \mathrm{H} \mathrm{H}^{\mathrm{O}} \\
40.6^{2} \\
8.67 \\
8.92 \\
28\end{array}$ & $\begin{array}{l}4.04 \\
\mathrm{Si} \mathrm{H} \mathrm{H}_{2} 0 \\
40.4^{2} \\
8.67 \\
8.86 \\
28\end{array}$ \\
\hline Al & 0.0151 & 0.0203 & 0.1563 & 21458 & 0.0316 & 0.1866 & \\
\hline$B$ & 0.0313 & 0.0254 & 2.7863 & 0.0332 & 0.0276 & 4.4608 & 4.3172 \\
\hline $\mathrm{Ba}$ & 0.1510 & 0.2056 & 0.0112 & 0.0948 & 0.1276 & 0.0092 & 0.0208 \\
\hline $\mathrm{Ca}$ & 0.0317 & 0.0559 & 0.2941 & 0.0744 & 0.0676 & 0.2774 & 0.3046 \\
\hline $\mathrm{Cd}$ & 0.0007 & 0.0048 & 0.0005 & 0.0008 & 0.0032 & 0.0006 & 0.0150 \\
\hline $\mathrm{Ce}$ & 0.0 & 0.0 & 0.0 & 0.0304 & 0.0912 & 0.0 & 0.1214 \\
\hline $\mathrm{Cr}$ & 0.0053 & 0.0064 & 0.0030 & 0.0016 & 0.0066 & 0.0134 & 0.0200 \\
\hline $\mathrm{Fe}$ & 0.0789 & 0.0350 & 0.0659 & 0.0848 & 0.0794 & 0.1364 & 0.2040 \\
\hline Mo & 0.1330 & 0.1476 & 1.3393 & 0.1906 & 0.1808 & 2.2948 & 2.0596 \\
\hline $\mathrm{Nd}$ & 0.0 & 0.0 & 0.0 & 0.0102 & 0.0196 & 0.0306 & 0.0510 \\
\hline$P$ & 0.0737 & 0.1537 & 0.1520 & 0.1222 & 0.0 & 0.2036 & 0.4936 \\
\hline Si & 21.945 & 22.053 & 34.116 & 21.552 & 22.216 & 40.732 & 40.012 \\
\hline $\mathrm{Ti}$ & 0.0044 & 0.0040 & 0.0018 & 0.0292 & 0.0066 & 0.0028 & 0.0122 \\
\hline Zn & 0.0050 & 0.0077 & 0.0717 & 0.0144 & 0.0100 & 0.2042 & 0.1838 \\
\hline $\mathrm{Zr}$ & 0.0020 & 0.0 & 0.0099 & 0.0372 & 0.0342 & 0.0916 & 0.0326 \\
\hline & 0.0270 & 0.0340 & 1.1 & 0.0470 & 0.0260 & 1.3 & 1.6 \\
\hline $\mathrm{U}(\mathrm{H}), \mathrm{ppb}^{(\mathrm{b})}$ & & & & 8.5 & 3.3 & 1430.0 & 1200.0 \\
\hline$U(R), p p b$ & 1.7 & 0.0 & 1070.0 & 7.5 & 3.6400 & 1240.0 & 1130.0 \\
\hline K & 0.1211 & 0.0617 & 0.2004 & 0.0 & 0.1270 & 0.2540 & 0.3386 \\
\hline $\mathrm{Mg}$ & 0.0295 & 0.0230 & 0.0288 & 0.0 & 0.0584 & 0.0584 & 0.0972 \\
\hline $\mathrm{Na}$ & 46.062 & 45.693 & 54.97 & 45.888 & 46.162 & 61.434 & 60.324 \\
\hline
\end{tabular}

(a) Results are reported in ppm unless otherwise noted.

(b) $(\mathrm{H})$ and (B) represent results from two different analysts. 
TABLE A.2. MCC-2, Monolith, $150^{\circ} \mathrm{C}$, Silicate Water (a)

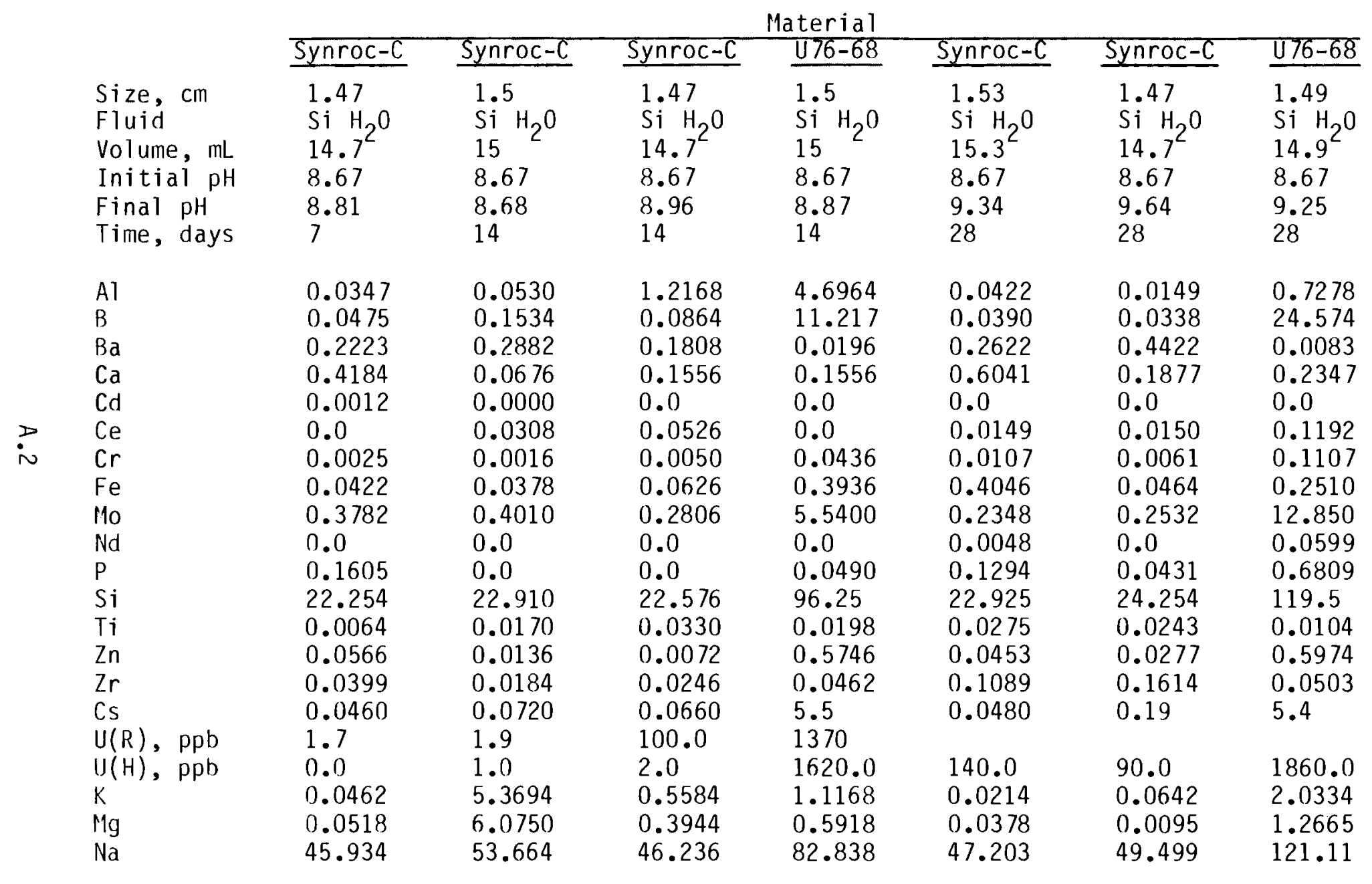

(a) Results are reported in ppm unless otherwise noted. 
APPENDIX B

LEACH TEST RESULTS FROM MCC-1 AND MCC-2 TESTS ON SYNROC-C AND 76-68 GLASS IN BRINE 
TABLE B.1. MCC-1, Monolith, $90^{\circ} \mathrm{C}$, Brine $(\mathrm{a})$

\begin{tabular}{|c|c|c|c|c|}
\hline & & $\mathrm{Ma}$ & & \\
\hline & Synroc-C & Synroc-C & Synroc-C & U76-68 \\
\hline $\begin{array}{l}\text { Size, cm } \\
\text { Fluid } \\
\text { Volume, } \mathrm{mL} \\
\text { Initial pH } \\
\text { Final pH } \\
\text { Time, days }\end{array}$ & $\begin{array}{l}4.05 \\
\text { Brine } \\
40.5 \\
4.43 \\
6.38 \\
14\end{array}$ & $\begin{array}{l}4.01 \\
\text { Brine } \\
40.1 \\
4.43 \\
3.72 \\
28\end{array}$ & $\begin{array}{l}3.99 \\
\text { Brine } \\
39.9 \\
4.43 \\
3.59 \\
28\end{array}$ & $\begin{array}{l}4.04 \\
\text { Brine } \\
40.4 \\
4.43 \\
4.88 \\
28\end{array}$ \\
\hline Al & 0.0 & 0.0 & 0.0 & 0.0 \\
\hline B & 0.134 & 0.134 & 0.104 & 3.683 \\
\hline $\mathrm{Ba}$ & 0.537 & 0.564 & 0.564 & 0.968 \\
\hline $\mathrm{Ca}$ & 0.353 & 0.794 & 0.424 & 2.454 \\
\hline $\mathrm{Cd}$ & 0.012 & 0.0 & 0.012 & 0.048 \\
\hline $\mathrm{Ce}$ & 0.509 & 0.680 & 0.512 & 0.337 \\
\hline $\mathrm{Cr}$ & 0.144 & 0.153 & 0.099 & 0.135 \\
\hline $\mathrm{Fe}$ & 0.156 & 0.192 & 0.240 & 0.162 \\
\hline Mo & 0.292 & 0.252 & 0.385 & 1.949 \\
\hline $\mathrm{Nd}$ & 0.453 & 0.571 & 0.344 & 0.521 \\
\hline$P$ & 0.000 & 0.0 & 0.0 & 0.0 \\
\hline Si & 0.615 & 0.977 & 0.688 & 17.225 \\
\hline $\mathrm{Ti}$ & 0.031 & 0.036 & 0.031 & 0.010 \\
\hline $\mathrm{Zn}$ & 0.0 & 0.0 & 0.0 & 4.630 \\
\hline $\mathrm{Zr}$ & 0.170 & 0.179 & 0.098 & 0.053 \\
\hline Cs & 0.0 & 0.0 & 0.0 & 0.920 \\
\hline$U(R), p p b$ & 0.0 & 0.0 & 0.0 & 119.0 \\
\hline$U(H), p p b$ & 0.0 & 0.0 & 0.0 & 140.0 \\
\hline
\end{tabular}

(a) Results are reported in ppm unless otherwise noted. 
TABLE B.2. MCC-2, Monolith, $150^{\circ} \mathrm{C}$, Brine ${ }^{(a)}$

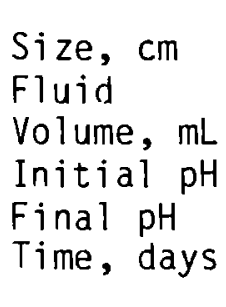

\begin{tabular}{lllll}
\multicolumn{4}{c}{ Material } \\
\cline { 1 - 1 } Synroc-C & & Synroc-C & Synroc-C & U76-68 \\
1.51 & 1.48 & & 1.42 & 1.45 \\
Brine & Brine & & Brine & Brine \\
15.1 & 14.8 & & 14.2 & 14.5 \\
4.43 & 4.43 & & 4.43 & 4.43 \\
3.7 & 3.8 & 3.77 & 3.99 \\
14 & 14 & 28 & 28
\end{tabular}

$\begin{array}{lllll}\mathrm{Al} & 0.0 & 0.0 & 0.0 & 0.029 \\ \mathrm{~B} & 0.149 & 0.149 & 0.217 & 18.331 \\ \mathrm{Ba} & 0.779 & 0.983 & 0.679 & 4.007 \\ \mathrm{Ca} & 0.847 & 1.306 & 0.980 & 11.047 \\ \mathrm{Cd} & 0.006 & 0.018 & 0.0 & 0.253 \\ \mathrm{Ce} & 0.854 & 0.339 & 0.178 & 0.349 \\ \mathrm{Cr} & 0.153 & 0.135 & 0.159 & 0.225 \\ \mathrm{Fe} & 0.222 & 0.288 & 0.398 & 0.243 \\ \mathrm{Mo} & 0.424 & 0.411 & 0.412 & 8.525 \\ \mathrm{Nd} & 0.575 & 0.340 & 0.119 & 0.593 \\ \mathrm{P} & 0.0 & 0.170 & 1.333 & 1.049 \\ \mathrm{Si} & 0.832 & 1.194 & 1.067 & 81.522 \\ \mathrm{Ti} & 0.057 & 0.046 & 0.058 & 0.037 \\ \mathrm{Zn} & 0.0 & 0.0 & 0.0 & 23.901 \\ \mathrm{Zr} & 0.554 & 0.644 & 0.589 & 0.844 \\ \mathrm{CS} & 0.0 & 0.0 & 0.0 & 4.0 \\ \mathrm{U}(\mathrm{R}), \mathrm{ppb} & & & & \\ \mathrm{U}(\mathrm{H}), \mathrm{ppb} & 70.0 & 50.0 & 0.0 & 2000.0 \\ \end{array}$

(a) Results are reported in ppm unless otherwise noted. 
APPENDIX C

LEACH TEST RESULTS FROM MCC-3 TESTS ON SYNROC-C AND 76-68 GLASS IN SILICATE WATER 


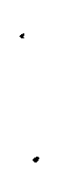


TABLE C.1. $M C C-3$, Powder, $90^{\circ} \mathrm{C}$, Silicate Water $(\mathrm{a})$

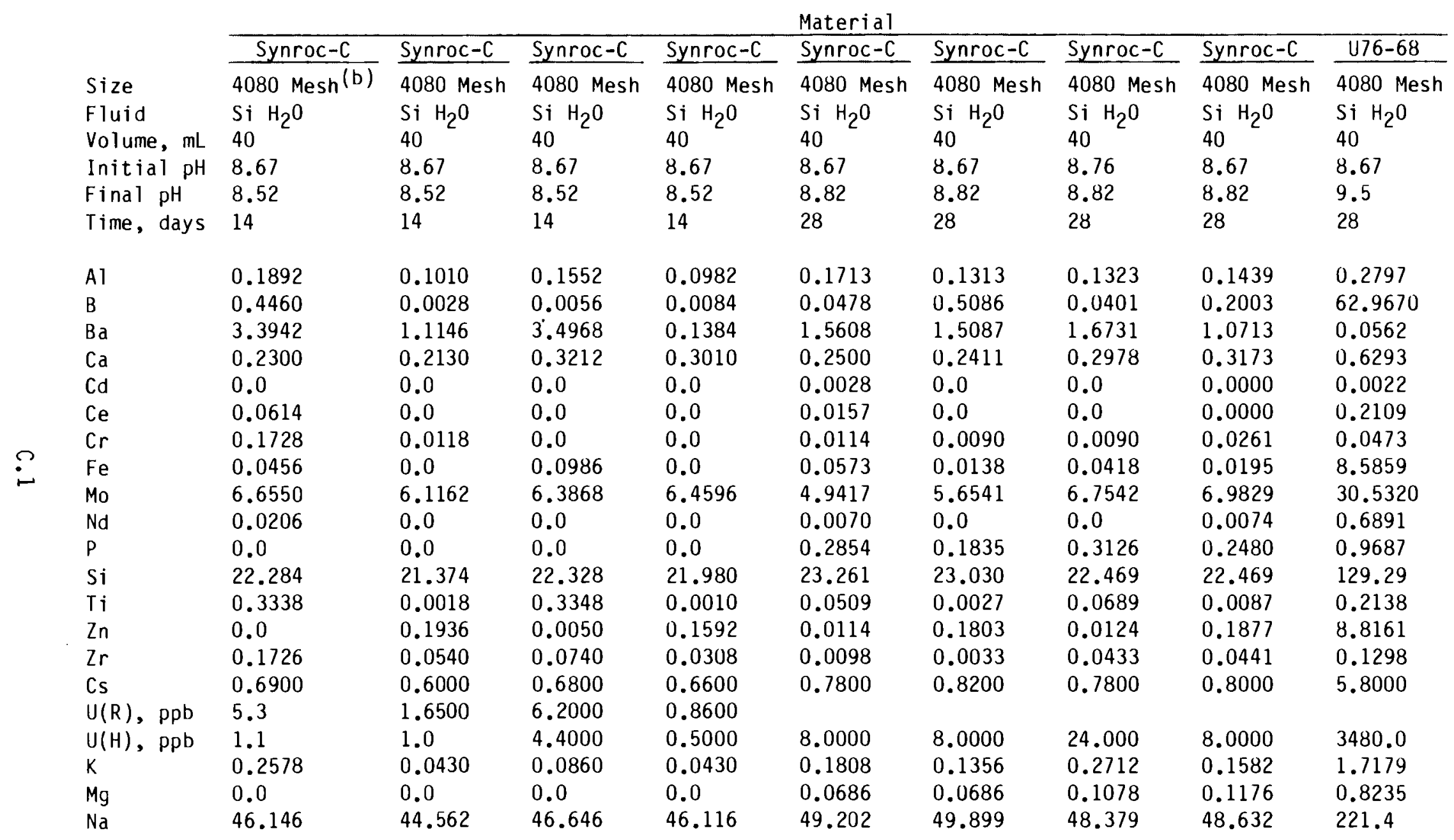


TABLE C.1. (contd)

Material

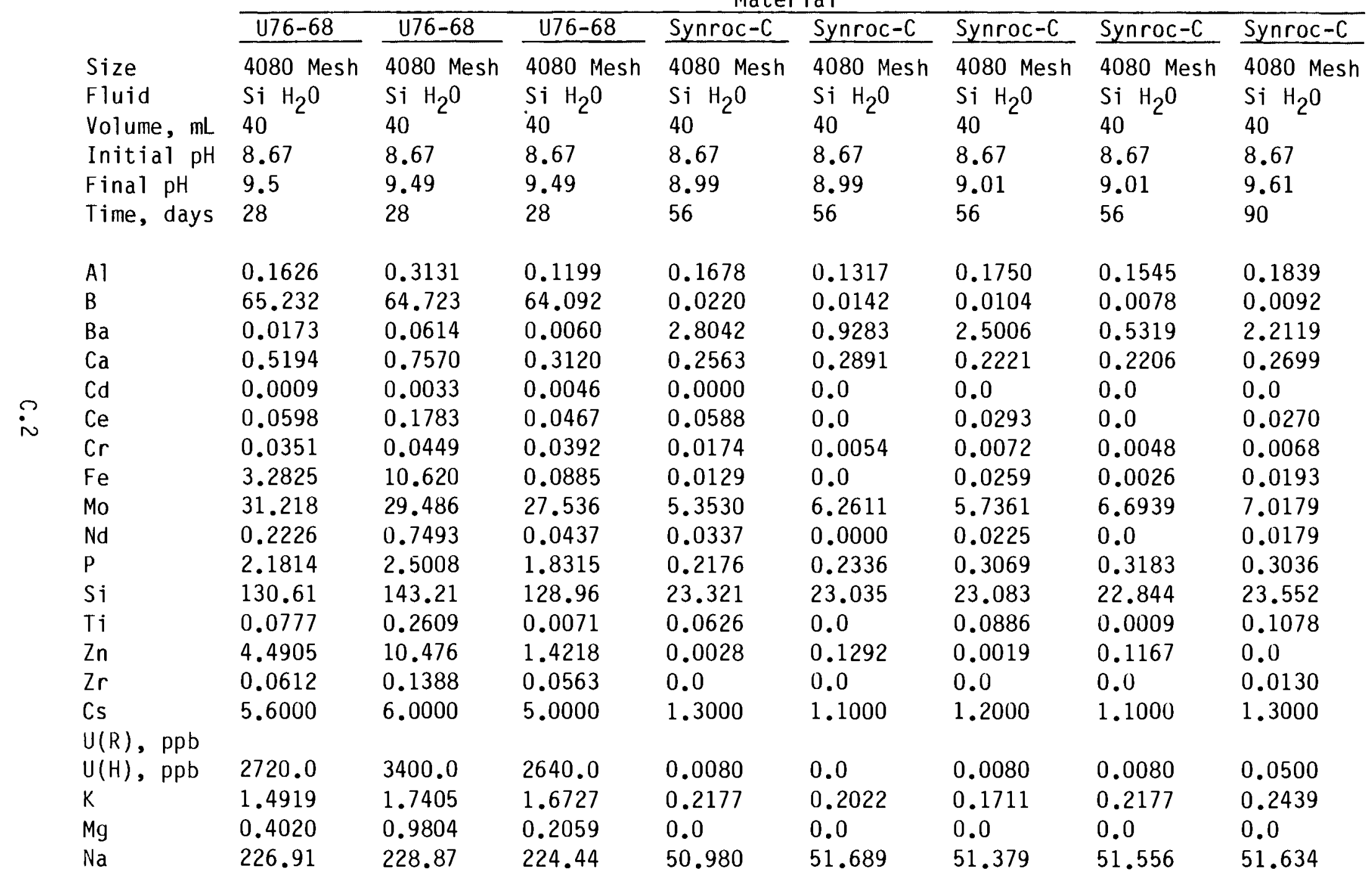


TABLE C.1: (contd)

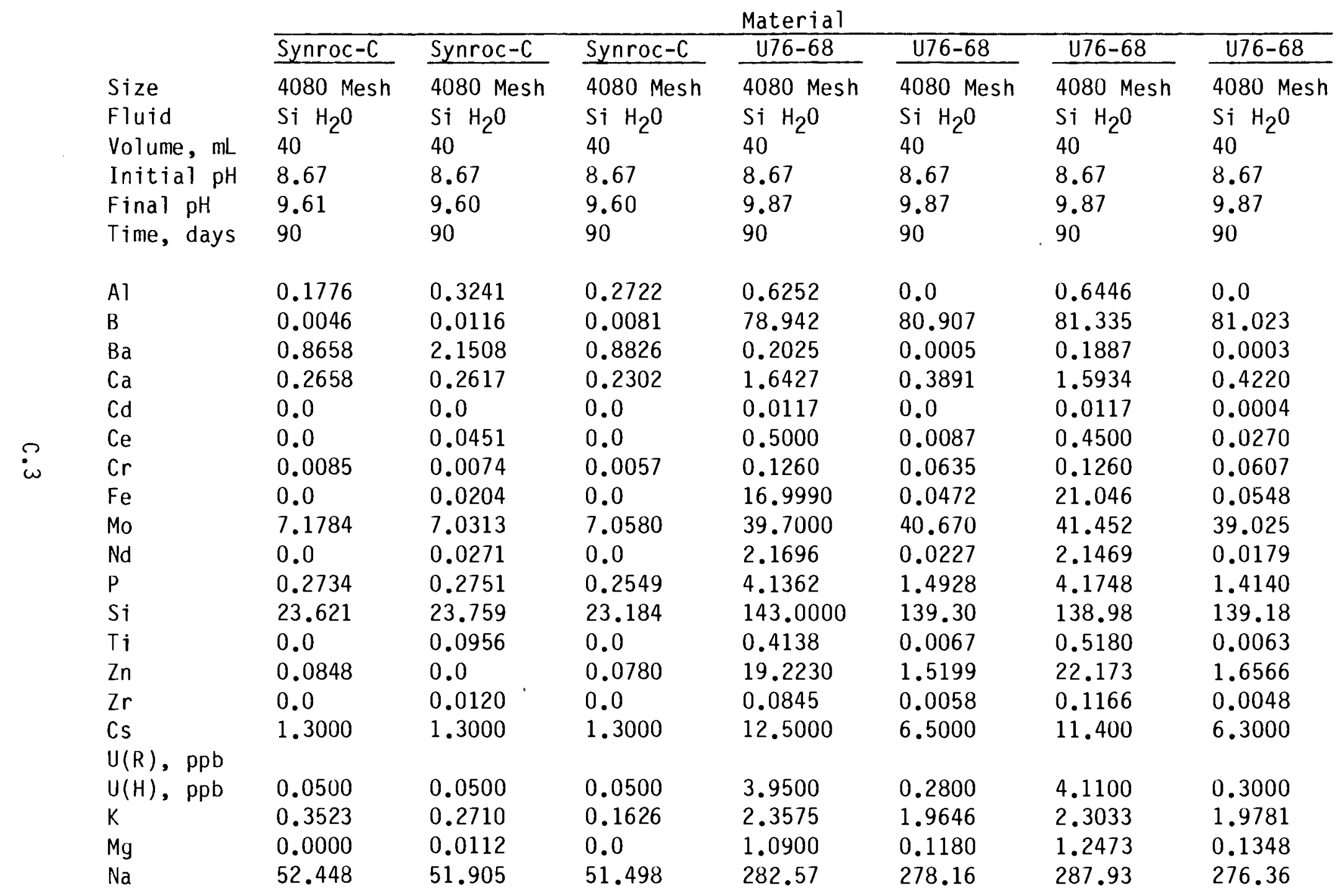

(a) Results are reported in ppm unless otherwise noted.

(b) $-40 /+80$ mesh. 
TABLE C.2. MCC-3, Powder, $150^{\circ} \mathrm{C}$, Silicate Water $(\mathrm{a})$

\begin{tabular}{|c|c|c|c|c|c|c|c|c|c|}
\hline & \multicolumn{9}{|c|}{ Material } \\
\hline & Synroc-C & Synroc-C & Synroc-C & Synroc-C & Synroc-C & Synroc-C & Synroc-C & Synroc-C & U76-68 \\
\hline Size & $4080 \operatorname{Mesh}^{(b)}$ & 4080 Mesh & 4080 Mesh & 4080 Mesh & 4080 Mesh & 4080 Mesh & 4080 Mesh & 4080 Mesh & 4080 Mesh \\
\hline Fluid & $\mathrm{Si} \mathrm{H} \mathrm{H}_{2} \mathrm{O}$ & $\mathrm{Si} \mathrm{H}_{2} \mathrm{O}$ & $\mathrm{Si} \mathrm{H}_{2} \mathrm{O}$ & $\mathrm{Si} \mathrm{H}_{2} \mathrm{O}$ & $\mathrm{Si} \mathrm{H}_{2} \mathrm{O}$ & $\mathrm{Si} \mathrm{H} \mathrm{H}_{2} \mathrm{O}$ & $\mathrm{Si} \mathrm{H}_{2} \mathrm{O}$ & $\mathrm{Si} \mathrm{H}_{2} \mathrm{O}$ & $\mathrm{Si} \mathrm{H}_{2} \mathrm{O}$ \\
\hline Volume, mL & 15 & & & 15 & & & & & \\
\hline Initial pH & 8.67 & 8.67 & 8.67 & 8.67 & 8.67 & 8.67 & 8.67 & 8.67 & 8.67 \\
\hline Final pH & 9.03 & 9.03 & 8.89 & 8.89 & 9.0 & 9.0 & 7.72 & 7.72 & 9.81 \\
\hline Time, days & 14 & 14 & 14 & 14 & 28 & 28 & 28 & 28 & 28 \\
\hline Al & 0.4808 & 0.4614 & 0.6300 & 0.5742 & 0.4675 & 0.3701 & 0.3693 & 0.3494 & 0.0 \\
\hline B & 0.1366 & 0.1032 & 0.0278 & 0.0196 & 0.1243 & 0.0879 & 0.0339 & 0.0163 & 244.27 \\
\hline $\mathrm{Ba}$ & 2.3966 & 0.6148 & 2.6750 & 0.4726 & 1.3779 & 0.2421 & 3.6239 & 1.3543 & 0.0020 \\
\hline $\mathrm{Ca}$ & 0.0946 & 0.1826 & 0.1318 & 0.1690 & 0.1900 & 0.1528 & 0.2514 & 0.4471 & 0.3385 \\
\hline $\mathrm{Cd}$ & 0.0 & 0.0 & 0.0 & 0.0 & 0.0015 & 0.0 & 0.0 & 0.0 & 0.0023 \\
\hline $\mathrm{Ce}$ & 0.0 & 0.0 & 0.0308 & 0.0 & 0.0094 & 0.0 & 0.0 & 0.0 & 0.0 \\
\hline $\mathrm{Cr}$ & 0.0234 & 0.0168 & 0.0184 & 0.0184 & 0.0247 & 0.0147 & 0.0053 & 0.0047 & 1.0648 \\
\hline $\mathrm{Fe}$ & 0.0 & 0.0 & 0.0 & 0.0 & 0.0251 & 0.0 & 0.0013 & 0.0 & 0.0798 \\
\hline Mo & 7.9830 & 8.0682 & 8.1534 & 8.0832 & 6.7925 & 8.0990 & 8.1889 & 8.6589 & 122.42 \\
\hline $\mathrm{Nd}$ & 0.0 & 0.0 & 0.0 & 0.0 & 0.0165 & 0.0 & 0.0 & 0.0 & 0.0 \\
\hline$P$ & 0.0870 & 0.0 & 0.0 & 0.0 & 0.1975 & 0.1309 & 0.2664 & 0.2181 & 8.7348 \\
\hline Si & 24.41 & 23.652 & 23.340 & 22.386 & 23.351 & 23.303 & 23.09 & 22.9 & 309.68 \\
\hline $\mathrm{Ti}$ & 0.0160 & 0.0010 & 0.0076 & 0.0 & 0.0013 & 0.0 & 0.0 & 0.0 & 0.0 \\
\hline $\mathrm{Zn}$ & 0.0222 & 0.1170 & 0.0028 & 0.1628 & 0.0027 & 0.1115 & 0.0013 & 1.3535 & 0.1307 \\
\hline $\mathrm{Zr}$ & 0.0232 & 0.0108 & 0.0 & 0.0 & 0.0 & 0.0 & 0.0 & 0.0 & 0.0388 \\
\hline Cs & 1.4000 & 1.6000 & 2.3000 & 2.1000 & 2.0 & 2.0 & 2.2000 & 2.2 & 1.1000 \\
\hline$U(R), p p b$ & 0.0 & 0.8600 & 0.0 & 0.8600 & & & & & \\
\hline$U(H), p p b$ & 1.0 & 0.5000 & 0.5000 & 0.5000 & 8.0 & 8.0 & 15.0 & 8.0000 & 3600.0 \\
\hline K & 0.1288 & 0.1718 & 0.2148 & 0.1718 & 0.1982 & 0.0 & 0.0 & 0.0152 & 4.2088 \\
\hline Mg & 0.0 & 0.0 & 0.0 & 0.0 & 0.0296 & 0.0 & 0.0 & 0.0 & 0.1718 \\
\hline $\mathrm{Na}$ & 47.408 & 46.016 & 46.838 & 45.424 & 51.866 & 53.228 & 51.185 & 50.802 & 716.76 \\
\hline
\end{tabular}


TABLE C.2. (contd)

\begin{tabular}{|c|c|c|c|c|c|c|c|c|c|}
\hline & & & & & & & & & \\
\hline & $076-68$ & Synroc-C & Synroc-C & Synroc-C & Synroc-C & Synroc-C & Synroc-C & $076-68$ & $076-68$ \\
\hline Size & 4080 Mesh & 4080 Mesh & 4080 Mesh & 4080 Mesh & 4080 Mesh & 4080 Mesh & 4080 Mesh & 4080 Mesh & 4080 Mesh \\
\hline Fluid & $\mathrm{Si} \mathrm{H}_{2} \mathrm{O}$ & $\mathrm{Si} \mathrm{H}_{2} \mathrm{O}$ & $\mathrm{Si} \mathrm{H}_{2} \mathrm{O}$ & $\mathrm{Si} \mathrm{H}_{2} \mathrm{O}$ & $\mathrm{Si} \mathrm{H}_{2} \mathrm{O}$ & $\mathrm{Si} \mathrm{H}_{2} \mathrm{O}$ & $\mathrm{Si} \mathrm{H}_{2} \mathrm{O}$ & $\mathrm{Si} \mathrm{H}_{2} \mathrm{O}$ & $\mathrm{Si} \mathrm{H}_{2} \mathrm{O}$ \\
\hline Volume, $\mathrm{mL}$ & & 15 & 15 & 15 & & 15 & 15 & & 15 \\
\hline Initial $\mathrm{pH}$ & 8.67 & 8.67 & 8.67 & 8.67 & 8.67 & 8.67 & 8.67 & 8.67 & 8.67 \\
\hline Final pH & 9.81 & 9.81 & 9.81 & 9.84 & 9.84 & 9.34 & 9.34 & 9.93 & 10.01 \\
\hline Time, days & 28 & 56 & 56 & 90 & 90 & 90 & 90 & 90 & 90 \\
\hline Al & 0.0 & 0.7545 & 0.7420 & 0.6039 & 0.5586 & 0.4730 & 0.4008 & 0.0000 & 0.0 \\
\hline B & 243.55 & 0.2331 & 0.1865 & 0.0890 & 0.0844 & 0.0462 & 0.0451 & 388.12 & 386.75 \\
\hline $\mathrm{Ba}$ & 0.0005 & 0.5926 & 0.1818 & 1.4220 & 0.1488 & 2.4656 & 0.6074 & 0.0070 & 0.0215 \\
\hline $\mathrm{Ca}$ & 0.5456 & 0.1282 & 0.1282 & 0.2151 & 0.1329 & 0.2480 & 0.2521 & 1.5865 & 0.6782 \\
\hline $\mathrm{Cd}$ & 0.0004 & 0.0 & 0.0 & 0.0 & 0.0 & 0.0 & 0.0 & 0.0127 & 0.0120 \\
\hline $\mathrm{Ce}$ & 0.0 & 0.0197 & 0.0000 & 0.0269 & 0.0 & & & & \\
\hline $\mathrm{Cr}$ & 1.0572 & 0.0235 & 0.0186 & 0.0165 & 0.0187 & 0.0250 & 0.0238 & 2.9078 & 3.2085 \\
\hline $\mathrm{Fe}$ & 0.0221 & 0.0126 & 0.0013 & 0.0130 & 0.0023 & 0.0096 & 0.0146 & 0.0667 & 1.9486 \\
\hline Mo & 122.06 & 7.4530 & 8.1128 & 8.4956 & 8.5156 & 8.7831 & 8.7229 & 195.84 & 194.81 \\
\hline $\mathrm{Nd}$ & 0.0000 & 0.0053 & 0.0116 & & & & & & \\
\hline $\mathrm{P}$ & 8.9690 & 0.1809 & 0.2084 & 0.1476 & 0.1191 & 0.1275 & 0.0973 & 4.9161 & 7.0077 \\
\hline$S \mathbf{i}$ & 271.95 & 26.924 & 26.113 & 24.588 & 23.667 & 24.381 & 23.414 & 242.29 & 318.86 \\
\hline $\mathrm{Ti}$ & 0.0 & 0.0055 & 0.0 & 0.0027 & 0.0 & 0.0024 & 0.0 & 0.0059 & 0.1317 \\
\hline $\mathrm{Zn}$ & 1.9395 & 0.0023 & 0.1731 & 0.0036 & 0.1352 & 0.0050 & 0.2186 & 3.3871 & 1.5700 \\
\hline $\mathrm{Zr}$ & 0.0126 & 0.0 & 0.0 & 0.0 & 0.0 & 0.0 & 0.0 & 0.0062 & 0.0259 \\
\hline Cs & 10.300 & 1.5000 & 1.3000 & 2.0000 & 1.8000 & 2.1000 & 1.8000 & 7.7000 & 9.6000 \\
\hline $\mathrm{U}(\mathrm{R}), \mathrm{ppb}$ & & & & & & & & & \\
\hline$U(H), p p b$ & 2200.0 & 50.0 & 1000.0 & & & & & & 3400.0 \\
\hline K & 3.7666 & 0.3266 & 0.2799 & 0.3387 & 0.2439 & 2.3575 & 0.2710 & 3.5091 & 3.9020 \\
\hline $\mathrm{Mg}$ & 0.1303 & 0.0060 & 0.0000 & 0.0169 & 0.0 & 0.0169 & 0.0 & 0.4326 & 0.2922 \\
\hline $\mathrm{Na}$ & 715.36 & 55.675 & 53.814 & 52.584 & 51.294 & 51.464 & 50.31 & 1010.6 & 1018.9 \\
\hline
\end{tabular}

(a) Results are reported in ppm unless otherwise noted.

(b) $-40 /+80$ mesh. 


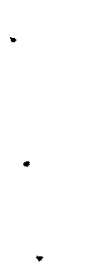

,

. 


\section{APPENDIX D}

LEACH TEST RESULTS FROM MCC-3 TESTS ON SYNROC-C AND 76-68 GLASS IN BRINE 

TABLE D.1. MCC-3, Powder, $90^{\circ} \mathrm{C}, \mathrm{Brine}(\mathrm{a})$

Material

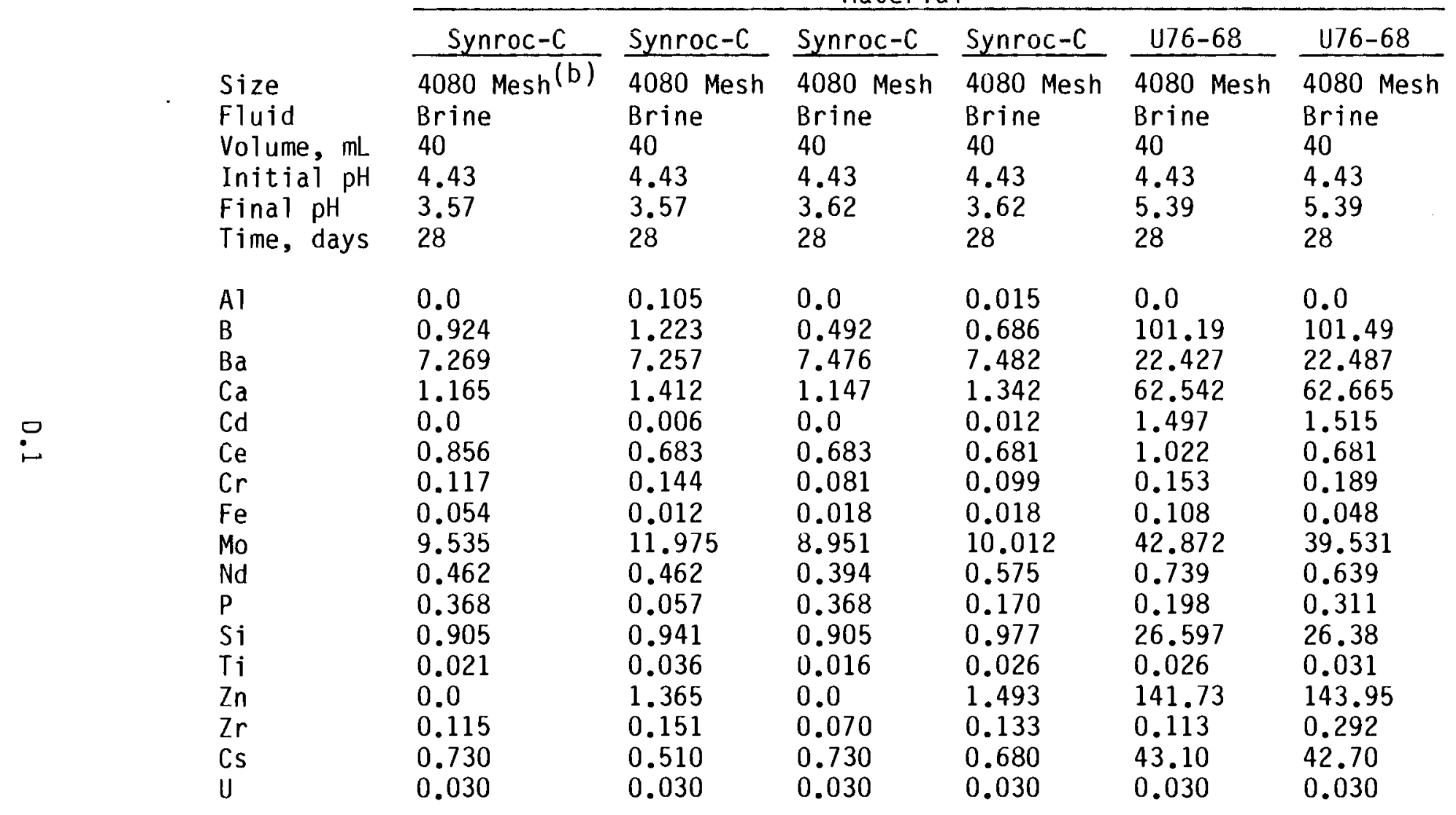

(a) Results are reported in ppm unless otherwise noted.

(b) $-40 /+80$ mesh. 
TABLE D.1. (contd)

Material

\begin{tabular}{|c|c|c|c|c|c|c|}
\hline \multirow[b]{3}{*}{$\begin{array}{l}\text { Size } \\
\text { Fluid } \\
\text { Volume, mL } \\
\text { Initial pH } \\
\text { Final pH } \\
\text { Time, days }\end{array}$} & \\
\hline & U76-68 & U76-68 & Synroc-C & Synroc-C & Synroc-C & Synroc-C \\
\hline & $\begin{array}{l}4080 \text { Mesh } \\
\text { Brine } \\
40 \\
4.43 \\
4.94 \\
28\end{array}$ & $\begin{array}{l}4080 \text { Mesh } \\
\text { Brine } \\
40 \\
4.43 \\
4.94 \\
28\end{array}$ & $\begin{array}{l}4080 \text { Mesh } \\
\text { Brine } \\
40 \\
4.43 \\
3.63 \\
90\end{array}$ & $\begin{array}{l}4080 \text { Mesh } \\
\text { Brine } \\
40 \\
4.43 \\
3.63 \\
90\end{array}$ & $\begin{array}{l}4080 \text { Mesh } \\
\text { Brine } \\
40 \\
4.43 \\
3.6 \\
90\end{array}$ & $\begin{array}{l}4080 \text { Mesh } \\
\text { Brine } \\
40 \\
4.43 \\
3.6 \\
90\end{array}$ \\
\hline A1 & 0.0 & 0.0 & 2.817 & 2.884 & 2.885 & 3.143 \\
\hline B & 102.53 & 102.39 & 0.485 & 0.497 & 0.497 & 0.474 \\
\hline $\mathrm{Ba}$ & 22.487 & 22.547 & 6.384 & 6.509 & 6.280 & 6.269 \\
\hline $\mathrm{Ca}$ & 62.63 & 62.383 & 4.042 & 4.233 & 3.987 & 4.124 \\
\hline $\mathrm{Cd}$ & 1.521 & 1.480 & 0.154 & 0.173 & 0.171 & 0.182 \\
\hline $\mathrm{Ce}$ & 1.024 & 0.510 & 1.700 & 1.608 & 1.789 & 1.881 \\
\hline $\mathrm{Cr}$ & 0.144 & 0.126 & 1.418 & 1.435 & 1.413 & 1.441 \\
\hline $\mathrm{Fe}$ & 0.036 & 0.042 & 0.594 & 0.598 & 0.717 & 0.613 \\
\hline Mo & 46.811 & 44.543 & 7.870 & 7.970 & 7.796 & 7.910 \\
\hline $\mathrm{Nd}$ & 0.752 & 0.521 & 1.613 & 1.661 & 1.701 & 1.705 \\
\hline$P$ & 0.028 & 0.000 & 7.648 & 7.414 & 7.850 & 7.481 \\
\hline $\mathrm{Si}$ & 25.954 & 25.62 & 5.916 & 5.985 & 6.054 & 6.054 \\
\hline $\mathrm{Ti}$ & 0.026 & 0.010 & 0.121 & 0.125 & 0.125 & 0.129 \\
\hline $\mathrm{Zn}$ & 141.98 & 143.54 & 0.170 & 1.782 & 0.1834 & 1.919 \\
\hline $\mathrm{Zr}$ & 0.131 & 0.193 & 0.192 & 0.168 & 0.178 & 0.168 \\
\hline Cs & 43.30 & 43.80 & 1.500 & 1.500 & 1.500 & 1.500 \\
\hline U & 0.030 & 0.030 & 0.050 & 0.050 & 0.050 & 0.050 \\
\hline
\end{tabular}


TABLE 0.2. MCC-3, Powder, $150^{\circ} \mathrm{C}, \mathrm{Brine}^{(\mathrm{a})}$

Material

\begin{tabular}{|c|c|c|c|c|c|c|}
\hline & Synroc-C & Synroc-C & Synroc-C & Synroc-C & U76-68 & U76-68 \\
\hline $\begin{array}{l}\text { Size } \\
\text { Fluid } \\
\text { Volume, mL } \\
\text { Initial pH } \\
\text { Final pH } \\
\text { Time, days }\end{array}$ & $\begin{array}{l}4080 \operatorname{Mesh}^{(b)} \\
\text { Brine } \\
15 \\
4.43 \\
4.04 \\
28\end{array}$ & $\begin{array}{l}4080 \text { Mesh } \\
\text { Brine } \\
15 \\
4.43 \\
4.04 \\
28\end{array}$ & $\begin{array}{l}4080 \text { Mesh } \\
\text { Brine } \\
15 \\
4.43 \\
4.11 \\
28\end{array}$ & $\begin{array}{l}4080 \text { Mesh } \\
\text { Brine } \\
15 \\
4.43 \\
4.11 \\
28\end{array}$ & $\begin{array}{l}4080 \text { Mesh } \\
\text { Brine } \\
15 \\
4.43 \\
4.34 \\
28\end{array}$ & $\begin{array}{l}4080 \text { Mesh } \\
\text { Brine } \\
15 \\
4.43 \\
4.34 \\
28\end{array}$ \\
\hline AT & 0.316 & 0.0 & 0.0 & 0.0 & 0.007 & 0.0 \\
\hline B & 2.520 & 2.564 & 1.416 & 1.744 & 255.21 & 254.02 \\
\hline $\mathrm{Ba}$ & 16.162 & 16.072 & 13.533 & 13.530 & 55.428 & 54.919 \\
\hline $\mathrm{Ca}$ & 4.748 & 4.678 & 4.854 & 5.207 & 153.49 & 151.90 \\
\hline $\mathrm{Cd}$ & 0.018 & 0.0 & 0.024 & 0.0 & 3.703 & 3.641 \\
\hline $\mathrm{Ce}$ & 0.683 & 0.340 & 0.680 & 0.337 & 1.355 & 0.838 \\
\hline $\mathrm{Cr}$ & 0.116 & 0.126 & 0.126 & 0.072 & 0.153 & 0.135 \\
\hline $\mathrm{Fe}$ & 0.936 & 0.156 & 0.444 & 0.168 & 0.174 & 0.108 \\
\hline Mo & 11.975 & 11.723 & 12.173 & 11.988 & 10.1714 & 9.866 \\
\hline $\mathrm{Nd}$ & 0.458 & 0.285 & 0.634 & 0.394 & 1.813 & 1.631 \\
\hline $\mathrm{P}$ & 0.510 & 0.340 & 0.510 & 0.680 & 1.302 & 0.028 \\
\hline Si & 1.484 & 1.339 & 5.356 & 5.138 & 73.675 & 70.997 \\
\hline $\mathrm{Ti}$ & 0.026 & 0.010 & 0.031 & 0.010 & 0.036 & 0.010 \\
\hline $\mathrm{Zn}$ & 0.0 & 1.686 & 0.0 & 2.829 & 354.02 & 352.09 \\
\hline $\mathrm{Zr}$ & 0.133 & 0.079 & 0.088 & 0.061 & 0.148 & 0.121 \\
\hline Cs & 1.400 & 1.400 & 1.500 & 1.700 & 117.0 & 114.0 \\
\hline 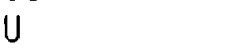 & 0.030 & 0.030 & 0.030 & 0.030 & 0.030 & 0.030 \\
\hline
\end{tabular}

(a) Results are reported in ppm unless otherwise noted.

(b) $-40 /+80$ mesh. 
TABLE D.2. (contd)

Material

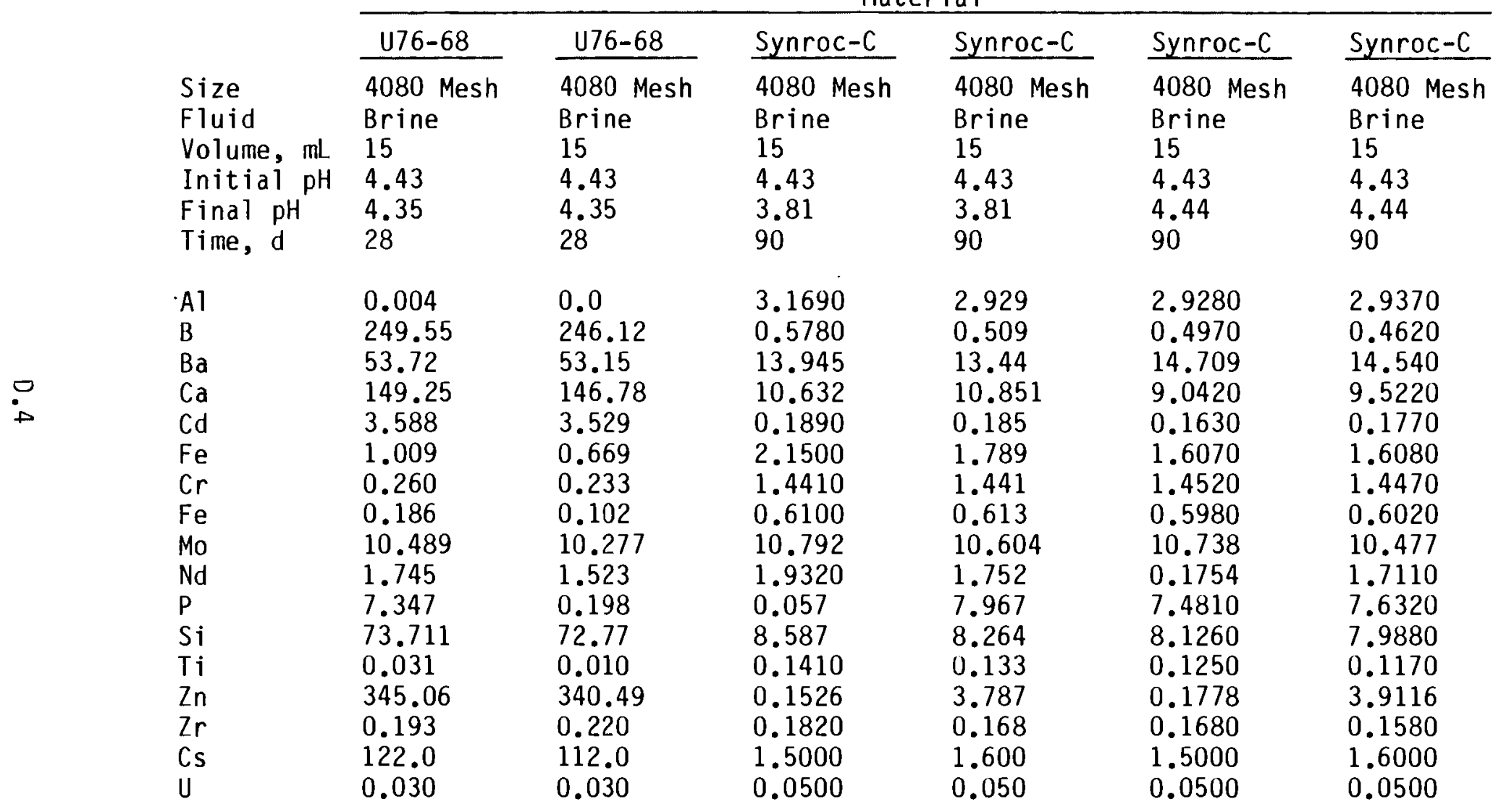




\section{DISTRIBUTION}

No. of

Copies

OFFSITE

30 DOE Technical Information Center

5 Geologic Repository Division

DOE Office of Civilian

Radioactive Waste Management

Forrestal Building

Washington, DC 20585

ATTN: J. W. Bennett, RW-20

C. R. Cooley, RW-4

M. W. Frei

B. C. Rusche, RW-1

R. Stein, RW-23

3 DOE Office of Defense Waste \& Byproducts Management GTN

Washington, DC 20545

ATTN: R. K. Hensser

J. E. Lytle, DP-12

R. D. Walton, Jr., DP-123

7 DOE Office of Terminal Waste

Disposal \& Remedial Action GTN

Washington, DC 20545

ATTN: J. E. Baublitz, NE-24

J. A. Coleman, NE-25

D. J. McGoff, NE-23

T. W. McIntosh, NE-25

W. R. Voigt, NE-20

H. F. Walter, NE-25

J. B. Zorn, NE-25

M. J. Bell

Division of Nuclear Materials

Safety \& Safeguards

Mail Station 881-SS

Nuclear Regulatory Commission

Washington, DC 20555
No. of

Copies

A. T. Clark

Division of Fuel Material Safety

Nuclear Regulatory Commission

Washington, DC 20555

W. J. Dircks

Office of the Executive

Director for Operations

Mail Station 6209

Nuclear Regulatory Commission

Washington, DC 20555

2 Environmental Protection Agency

Office of Radiation Programs

401 M Street, S.W.

Washington, DC 20460

ATTN: D. Egan

G. L. Sjoblom

3 DOE Albuquerque Operations Office

P.0. Box 5400

Albuquerque, NM 87185

ATTN: K. A. Carlson

M. H. McFadden

J. McGough

P. G. Hagan

Joint Integration Office

Bldg. 3, 2nd Floor

2201 San Pedro N.E.

Albuquerque, NM 87110

E. Maestas

DOE West Valley Operations Office

P.0. Box 191

West Valley, NY 14171 
No. of

Copies

3 DOE Idaho Operations Office

550 Second Street

Idaho Falls, ID 83401

ATTN: M. J. Barainca

J. P. Hamric

J. B. Whitsett

F. T. Fong

DOE San Francisco Operations

1333 Broadway

Oakland, CA 94612

M. R. Jugan

DOE Oak Ridge Operations Office

P.0. Box E

Oak Ridge, TN 37830

S. A. Mann

DOE Chicago Operations Office

9800 South Cass Avenue

Argonne, IL 60439

J. 0. Neff

DOE National Waste Program Office

505 King Avenue

Columbus, $\mathrm{OH} 43201$

W. J. Brumley

DOE Savannah River Operations Office

P.0. Box A

Aiken, SC 29801

D. L. Vieth

DOE Nevada Operations Office P.0. Box 14100

Las Vegas, NV 89114

2 Argonne National Laboratory

9700 South Cass Avenue

Argonne, IL 60439

ATTN: M. J. Steindler

L. E. Trevorrow
No. of

Copies

C. S. Abrams

Argonne National Laboratory

P.0. Box 2528

Idaho Falls, ID 83401

2 Battelle Memorial Institute

Office of Crystalline Repository Development

9800 South Cass Avenue

Argonne, IL 60439

ATTN: W. J. Madia

B. D. Shipp

3 Battelle Memorial Institute

Project Management Division 505 King Avenue

Columbus, $\mathrm{OH} 43201$

ATTN: W. A. Carbeiner/

S. H. Basham

J. F. Kircher

B. Rawles

F. Holzer

Lawrence Livermore National

Laboratory

University of California

P.0. Box 808

Livermore, CA 94550

D. T. Oakley, MS 671

Los Alamos Scientific Laboratory P.0. Box 1663

Los Alamos, NM 87544

6 Oak Ridge National Laboratory

P.0. Box Y

Oak Ridge, TN 37830

ATTN: J. 0. Blomeke

W. D. Burch

R. T. Jubin

L. J. Mezga

T. H. Row 
No. of

Copies

5 Sandia Laboratories

P.0. Box 5800

Albuquerque, NM 87185

ATTN: D. R. Anderson

J. F. Ney

R. W. Lynch

W. Weart

Technical Library

J. R. Berreth

Westinghouse Idaho Nuclear

Co., Inc.

P.0. Box 4000

Idaho Fal1s, ID 83401

7 E. I. du Pont de Nemours Company

Savannah River Laboratory

Aiken, SC 29801

ATTN: M. D. Boersma

J. G. Glasscock

E. J. Hennelly

C. M. Jantzen

J. R. Knight

M. J. Plodinec

C. T. Randa 11

E. A. Jennrich

EG\&G Idaho

P.0. Box 1625

Idaho Falls, ID 83415

V. Ricks

EG\&G

1580 Sawti11

P.0. Box 1680

Idano Falls, ID 83415

G. W. Meyers

Atomics International Division

Rockwell Internationa 1

8900 DeSoto Avenue

Canoga Park, CA 91304
No. of

Copies

T. H. Pigford

Department of Nuclear

Engineering

University of California

Berkeley, CA 94720

M. E. Spaeth

Science Applications, Inc.

2769 South Highland

Las Vegas, NV 89109

J. F. Strah1

Weston

2301 Research Boulevard

Third Floor

Rockville, MD 20850

R. Williams

Electric Power Research Institute

$3412 \mathrm{Hillview} \mathrm{Avenue}$

P.0. Box 10412

Palo Alto, CA 94304

5 West Valley Nuclear Services Company

P.0. Box 191

West Valley, NY 14171

ATTN: C. C. Chapman

J. C. Cwynar

J. L. Knabenschuh

J. E. Krauss

J. M. Pope

J. W. Bartlett

The Analytic Sciences

Corporation

6 Jacob Way

Reading, MA 01867

W. A. Freeby/J. L. Jardine

Bechtel National, Inc.

P.0. Box 3965

San Francisco, CA 94119 
No. of

Copies

Librarian

Westinghouse Electric

Corporation

Technical Library

P.0. Box 2078

Carlsbad, NM 88220

L. L. Hench

Department of Materials Science \& Engineering

University of Florida

Gainesville, FL 32611

J. L. Larocca, Chairman

Energy Research \& Development Authority

Empire State Plaza

Albany, NY 12223

R. G. Post

College of Engineering

University of Arizona

Tucson, AZ 85721

\section{ONSITE}

12 DOE Richland Operations Office

J. H. Anttonen

E. A. Bracken

G. J. Bracken

C. R. DeLannoy

R. D. Izatt

N. T. Karagianes

M. J. Plahuta

J. L. Rhoades

M. W. Shupe

J. J. Sutey

J. D. White

J.K.W. Wukelik
No. of

Copies

10 Rockwell Hanford Operations

R. N. Gurley

H. E. McGuire

J. W. Patterson

R. D. Prosser

I. E. Reep

R. J. Thompson

T. B. Venziano

D. D. Wodrich

R. D. Wojtasek

File Copy

UNC United Nuclear Industries

T. E. Dabrowski/W. J. Kyriazis

2 Westinghouse Hanford Company

R. E. Lerch

J. D. Watrous

59 Pacific Northwest Laboratory

W. J. Bjorklund

H. T. Blair

W. F. Bonner

D. J. Bradley

R. A. Brouns

L. R. Bunnel1

L. L. Burger/L. A. Bray/ R. D. Scheele

H. C. Burkholder

J. R. Carrell

R. D. Dierks

S. K. Edler

R. W. Goles

M. S. Hanson

H. A. Haerer

L. K. Holton 
No of

Copies
J. H. Jarrett
D. E. Knowlton
S. S. Koegler
M. R. Kreiter
W. W. Laity
L. T. Lakey/K. M. Harmon
J. M. Latkovich
J. L. McElroy
G. L. McVay
J. E. Mendel/M. D. Merz/
G. B. Mellinger
J. E. Minor
L. G. Morgan
D. R. Montgomery

No. of

Copies

T. R. Myers

R. D. Peters

M. E. Peterson

A. M. Platt/R. E. Nightingale

J. A. Powe 11

W. A. Ross

K. J. Schneider

P. A. Scott

J. W. Shade (10)

D. H. Siemens

G. L. Tingey/G. A. Jensen

Publishing Coordination (2)

Technical Information (5) 


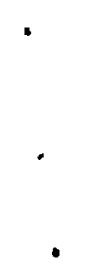

$\bullet$ 